\title{
Enhanced nutrient regeneration at commercial hard clam (Mercenaria mercenaria) beds and the role of macroalgae
}

\author{
Anna E. Murphy*, Iris C. Anderson, Mark W. Luckenbach \\ Virginia Institute of Marine Science, College of William \& Mary, Gloucester Point, Virginia 23062, USA
}

\begin{abstract}
High densities of bivalves found in aquaculture can exert 'top-down' control on primary production through feeding while simultaneously influencing local 'bottom-up' effects on production by enhancing nutrient recycling. Thus bivalves may decrease or increase localized eutrophication (sensu Nixon), depending on environmental conditions and specific culture practices. This study investigates hard clam aquaculture influence on benthic nutrient regeneration and metabolism, seasonally using in situ incubations. Effects of macroalgae, which proliferate on predator-exclusion nets at cultivation sites, are also investigated. Ammonium $\left(\mathrm{NH}_{4}{ }^{+}\right)$and phosphate effluxes averaged 154 and 100 times higher, respectively, at clam beds compared to reference sediments. Macroalgae decreased $\mathrm{NH}_{4}{ }^{+}$efflux from clam beds by 20 to $77 \%$, while having no significant effect on phosphate. Nutrient release from clam beds to the water column supports macroalgal growth, supplying nitrogen in excess of macroalgal demand in spring and fall and $58 \%$ of demand in summer, suggesting $\mathrm{N}$ recycling in the benthos is sufficient to support macroalgal production. As a bio-extractive practice, clam aquaculture is a net sink for nutrients in aquatic systems. However, our data suggest clam cultivation may influence eutrophication locally by facilitating increased macroalgal production due to increased benthic nutrient recycling. Given the high capacity for macroalgae to temporarily sequester nutrients released from the clam beds, macroalgal harvest may be an effective means to negate these effects of the clams and remove unwanted nutrients from the ecosystem.
\end{abstract}

KEY WORDS: Aquaculture $\cdot$ Clam $\cdot$ Shellfish $\cdot$ Macroalgae $\cdot$ Eutrophication $\cdot$ Nitrogen cycling

\section{INTRODUCTION}

Coastal and estuarine ecosystems remove, transform, and sequester nutrients and organic matter and provide diverse habitats and resources to commercially valuable fish and bivalve species. Due to their location along the land-sea continuum, these ecosystems are vulnerable to anthropogenic activities, which accelerate organic matter and nutrient delivery to the water, posing risks of eutrophication (Nixon 1995). Defined by Nixon (1995) as the increase in the rate of supply of organic matter to an eco- system, eutrophication has become an increasingly pertinent global concern as it decreases ecosystem function and economic value (NRC 2000, Bricker et al. 2008). Eutrophication can be triggered by a number of factors including changes in grazer activity, increased nutrient input from the watershed or adjacent waters, and increased organic matter input. Eutrophication may be characterized by phytoplankton or macroalgal blooms. The dominance of these primary producers varies on both seasonal and annual time scales with a variety of natural and anthropogenic drivers (Nixon et al. 2001, Valiela et al. 1997). 
Aside from land-based human perturbations, such as urban development, agriculture, and wastewater treatment, growth of in-water aquaculture represents an expanding anthropogenic perturbation to coastal waters. Shellfish aquaculture has become an important feature in many coastal waters worldwide, and understanding its impact within the context of increasingly eutrophic waters is necessary to ensure its sustainability. The effect of bivalve aquaculture on nutrient cycling and eutrophication is the subject of ongoing debate (Lindahl et al. 2005, Stadmark \& Conley 2011, Rose et al. 2012). Depending on a variety of environmental factors, bivalves can exert 'topdown' (i.e. filter-feeding) and influence 'bottom-up' (i.e. increase nutrient recycling) control on primary production and thus may decrease or increase localized primary production, respectively.

Bivalve aquaculture, which does not require exogenous feed, may modulate eutrophication by removing phytoplankton (Gren et al. 2009, Bricker et al. 2014, Rose et al. 2014). Suspension feeding bivalves exert direct 'top-down' control on phytoplankton biomass through feeding, which reduces water column particulate organic matter (Cloern 1982, Officer et al. 1982, Cohen et al. 1984, Strayer et al. 1999). In a cultivation setting, the nutrients assimilated within the tissues of the bivalves are permanently removed from the aquatic system upon harvest. Additionally, denitrification, a microbial process that converts bioavailable nitrogen to $\mathrm{N}_{2}$ gas, may be enhanced in aquaculture operations under certain environmental conditions (Kaspar et al. 1985, Carlsson et al. 2012). Nutrient removal by bivalves has been proposed as an approach to mitigate eutrophication (Lindahl et al. 2005, Rose et al. 2012, Bricker et al. 2014, Petersen et al. 2014); however, indirect bottom-up effects of high densities of bivalves must be considered.

Bivalves indirectly enhance primary production by increasing benthic nutrient fluxes to the water column (Doering et al. 1986, Bartoli et al. 2003). Commercial-scale bivalve aquaculture has been shown to reduce sediment and water quality and cause local nutrient enrichment (De Casabianca et al. 1997, Bartoli et al. 2001, Stadmark \& Conley 2011). Bivalves are a direct source of nutrients to the water column through active excretion of ammonium $\left(\mathrm{NH}_{4}{ }^{+}\right)$, soluble reactive phosphorous (SRP), and dissolved organic nitrogen and carbon (DON, DOC) (Sma \& Baggaley 1976, Magni et al. 2000). High bivalve biodeposition rates along with the gear used for cultivation (i.e. cages, nets, and racks) enhance sedimentation (Grenz et al. 1990, Spencer et al. 1997, Smaal et al. 2001), resulting in organically enriched sediments, increased microbial remineralization, reduced dissolved oxygen (DO), and sulfide accumulation causing fluxes of $\mathrm{NH}_{4}{ }^{+}$and SRP out of sediments (Giles \& Pilditch 2006, Nizzoli et al. 2007). Sulfidic and low oxygen conditions inhibit coupled nitrification-denitrification, further enhancing $\mathrm{NH}_{4}{ }^{+}$fluxes to the water column (Joye \& Hollibaugh 1995, Heijs et al. 2000). Additionally, the aquaculture gear serves as hard substrate and may promote macrophyte attachment and growth, thus increasing local eutrophication by increasing organic C production.

Environmental factors (including hydrodynamics, residence time, temperature, light, and ambient nutrient concentrations) likely play a role in determining the extent to which bivalves facilitate or dampen eutrophication. Additionally, the particular bivalve species and the cultivation methods employed influence impacts on the environment, posing a challenge in generalizing across all bivalve aquaculture. Studies on the effects of cultivating epibenthic organisms (such as mussels and oysters) on sediment biogeochemistry have demonstrated increased nutrient regeneration in sediments (Hatcher et al. 1994, Gilbert et al. 1997, Chapelle et al. 2000, Christensen et al. 2003, Giles \& Pilditch 2006). Few studies have investigated biogeochemical cycling within cultured clam beds and its impacts on eutrophication. Unlike oysters and mussels, which are typically grown suspended in the water column, clams are cultured within the sediment, and as a result their effects on sediment nutrient dynamics are quite different.

Through bioturbation, clams may directly increase advection and diffusion, changing sediment DO and nutrient profiles and subsequently biogeochemical process rates (Nizzoli et al. 2006). However, use of predator exclusion nets (i.e. plastic mesh placed flush on the sediment surface) by clam growers on the US east coast may reduce exchanges between overlying water and sediments. In addition, ephemeral macroalgae on the net surface affect DO, release particulate organic carbon (POC) and DOC to the sediments, and temporarily sequester nutrients sourced from the clam beds. Clam growers frequently sweep the nets of accumulated macroalgae, which are allowed to drift away and decompose, releasing nutrients and potentially depleting DO in adjacent waters. Upon senescence due to density-dependent factors (e.g. self-shading) and/or environmental factors (e.g. increase in temperature), ephemeral macroalgae in the coastal bays of Virginia degrade rapidly, releasing nutrients and decreasing DO (Tyler et al. 2001, Hardison et al. 2010). 
As aquaculture becomes more prevalent in coastal waters, an understanding of its interactions with the surrounding ecosystem, particularly with respect to nutrient cycling, is necessary to avoid creating eutrophic conditions. This study investigated the effects of hard clam Mercenaria mercenaria aquaculture on benthic respiration and nutrient regeneration, specifically with regard to modifying fluxes to the water column and contributing to seasonal macroalgal growth. The study assessed the importance of macroalgae in modulating benthic net community production (NCP) and nutrient fluxes across the sediment water interface at the clam aquaculture sites. We hypothesized that clam beds are net heterotrophic, resulting in a release of nutrients to the water column, whereas uncultivated sediment sites are net autotrophic and a sink for nutrients. We expected macroalgae to decrease nutrient effluxes at clam beds and shift community metabolism to net autotrophy (see Fig. 4).

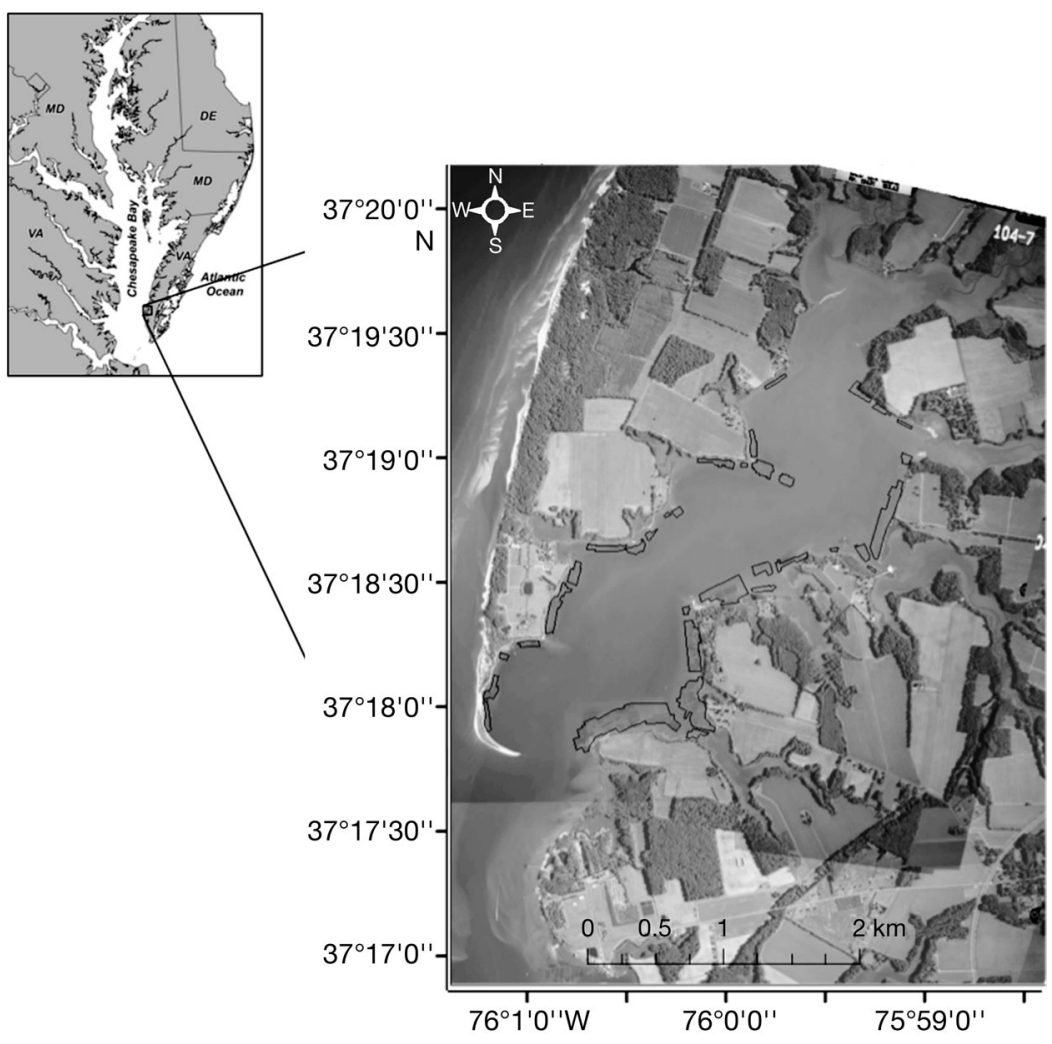

Fig. 1. Aerial photograph of Cherrystone Inlet, Chesapeake Bay, USA, taken in 2012. Black polygons delineate active clam aquaculture operations

\section{MATERIALS AND METHODS}

\section{Site description}

Field experiments were conducted in May, July, and October 2012 in Cherrystone Inlet, a small tributary $\left(5.7 \mathrm{~km}^{2}\right)$ of Chesapeake Bay, located on the bayside of the eastern shore of Virginia, USA (Fig. 1). Average depth is $<2 \mathrm{~m}$ and approx. one-third of its subtidal bottom is partitioned into private shellfish leases, most used to grow hard clams Mercenaria mercenaria. Hard clam aquaculture on the east coast of the US typically involves planting hatchery-reared juvenile clams in sandy subtidal sediments, covering the beds with plastic predator exclusion nets, and mechanically harvesting the clams at market size (3$4 \mathrm{~cm}$ shell height) after about $2 \mathrm{yr}$. The clams in Cherrystone Inlet are planted at $700-800$ ind. $\mathrm{m}^{-2}$, with an estimated standing stock of about 100 million cultured clams within the tributary (Condon 2005). The sampling sites for this study were located in the southern portion of the inlet close to the mouth that empties into Chesapeake Bay. The sites experience little salin- ity variation, which is driven largely by rain events. Macroalgae, including Ulva lactuca, Gracilaria spp., Agardhiella tenera, and Cladophora sp., are present on the commercial clam bed nets throughout the year.

\section{Experimental design}

In each sampling month, fluxes were measured at 3 randomly selected clam beds and 3 bare sediment sites located in line with the clam beds, perpendicular to the shore. The clam beds consisted of mature, close to market size clams (approx. 3-4 cm shell height), and the nets had not been recently swept of macroalgae by the aquaculturists. In situ flux treatments included: clams plus macroalgae in the light (CML) and in the dark (CMD), clams without macroalgae in the light (CL) and dark (CD), bare sediments in the light (BL) and dark (BD) and water blanks in the light (WL) and dark (WD). One clam bed and one bare site were sampled each day, over 3 consecutive days. All treatments were conducted in triplicate each day, providing $\mathrm{n}=9$ per sampling month and treatment. As the bare sites were typically deeper 
than the clam sites, cores were elevated to the depth of the clam bed cores to ensure similar ambient light levels. On each clam bed, 3 sets of randomly-positioned blocks of 4 flux chambers, one for each clam treatment $(\mathrm{CML}, \mathrm{CMD}, \mathrm{CL}$, and $\mathrm{CD})$, were inserted through a hole in the predator exclusion net. At the bare site, 3 replicates of $\mathrm{BL}, \mathrm{BD}, \mathrm{WL}$, and WD treatments were established. Opaque shade cloth covered the dark cores to prevent light penetration, verified by measuring the light under the cloth using a Li-Cor quantum deck sensor (LI-190SA).

Ambient macroalgal biomass was obtained by randomly tossing a ring sampler $\left(0.014 \mathrm{~m}^{2}\right) 5$ times on clam nets near the flux incubation nets, to avoid disturbing these sites. Macroalgal wet weight was scaled to the size of the flux chambers, and the appropriate amount of macroalgae was added to the cores. Ambient macroalgal biomass and community composition at the clam farm varied seasonally, and the macroalgae placed in the experimental cores reflected this seasonality.

\section{Benthic metabolism and nutrient flux measurements}

During each sampling month, in situ flux incubations were conducted on ebbing tides on days with minimal cloud cover to allow adequate light levels during the experiments. In situ incubations minimized disturbance to the sediments and clams and ensured clams were not starved of food prior to the experiments. Flux chambers (clear acrylic cores, $13.3 \mathrm{~cm}$ i.d. by $40 \mathrm{~cm}$ tall) were inserted into the sediment to a depth resulting in a $20 \mathrm{~cm}$ water column, allowed to equilibrate for $1 \mathrm{~h}$, then capped, excluding air bubbles. Central motors were used to power small magnetic stir bars suspended below each core cap to prevent gradients from developing. Half of the flux chambers were covered with opaque fabric to prevent light penetration and obtain respiration values under dark conditions. Water blanks (cores filled with ambient water) were sampled to distinguish water column from sediment processes. Overlying water in each of the chambers was sampled hourly over a $4 \mathrm{~h}$ incubation period. DO was measured by pulling the sample with a syringe into an airtight chamber containing a Hach LDO101 Luminescent DO sensor. Dissolved inorganic carbon (DIC) samples, stored in $8 \mathrm{ml}$ hungate tubes (Bellco Glass), were preserved with 15 $\mu \mathrm{l}$ saturated mercuric chloride and kept cold under water until analyzed within 1 mo of collection using a Li-Cor 6252 infrared gas analyzer (Neubauer \&
Anderson 2003). Samples collected concurrently with the DO and DIC samples were filtered and frozen until analysis for DIN, dissolved inorganic phosphate (DIP), DOC, DON, and chlorophyll a (chl a) as described below.

\section{Flux calculations}

Hourly fluxes for each analyte were calculated as:

$$
\text { Flux }=(m \times V) / A
$$

where $m$ is equal to the slope of the linear regression of concentration $(\mu \mathrm{M}$ or $\mathrm{mM})$ versus time $(\mathrm{h}) ; V$ is equal to the volume of water in the flux chamber (1); and $A$ is the sediment surface area within the chamber $\left(\mathrm{m}^{2}\right)$. A flux from the sediment to the water column is positive, while a flux to the sediment from the water column is a negative value. Water blank fluxes were subtracted from the whole core fluxes to obtain a benthic community flux. Benthic metabolism (DIC

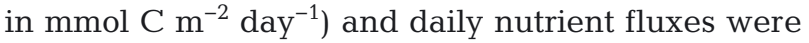
calculated as follows:

$$
\begin{gathered}
R=F_{\mathrm{d}} \times 24 \mathrm{~h} \\
\mathrm{GPP}=h_{\mathrm{l}} \times\left(F_{\mathrm{l}}-F_{\mathrm{d}}\right) \\
\mathrm{NCP}=\mathrm{GPP}+R \\
\text { Daily nutrient flux }=\left(F_{1} \times h_{\mathrm{l}}\right)+\left(F_{\mathrm{d}} \times h_{\mathrm{d}}\right)
\end{gathered}
$$

where $R$ is community respiration, GPP is gross primary production, NCP is net benthic community production, $F_{\mathrm{d}}$ and $F_{1}$ are hourly fluxes in the dark and light, respectively $\left(\mathrm{mmol} \mathrm{m} \mathrm{m}^{-2} \mathrm{~h}^{-1}\right), h_{\mathrm{d}}$ and $h_{\mathrm{l}}$ are the number of hours of dark and light in a day, which varied seasonally. When NCP is negative, GPP exceeds $R$ and the system is net autotrophic with net uptake of DIC. Net heterotrophy and thus net release of DIC is represented by a positive NCP.

\section{Clam and macroalgal measurements}

Upon completion of the flux measurements, all clams were removed from each chamber and the ash-free dry weight (DW) determined by the difference in dry weight prior to and after combusting at $500^{\circ} \mathrm{C}$ for $5 \mathrm{~h}$. All macroalgae were removed from the CML and CMD chambers, and the DW was determined for each species present. A subset of dried macroalgal tissue samples from the dominant species during each sampling month were stored in the freezer until analyzed on a Carlo Erba (Thermo Electron Flash EA 1112 Series) elemental analyzer 
for POC (samples were acidified prior to analysis) and total nitrogen content.

\section{Estimating clam excretion}

To estimate the contribution of clam metabolism (i.e. excretion) to the net $\mathrm{NH}_{4}{ }^{+}$flux measurements at the clam sites, we used an equation derived by Sma \& Baggaley (1976):

$$
\log _{10}(E)=0.94 \times \log _{10}(\mathrm{DW})+1.33
$$

where $E$ is equal to the excretion rate $\left(\mu \mathrm{mol} \mathrm{NH}_{4}{ }^{+}\right.$ ind. ${ }^{-1} \mathrm{~d}^{-1}$ ) and DW is the tissue dry weight ( $\mathrm{g}$ ) of an individual clam. Sma \& Baggaley (1976) measured the production of $\mathrm{NH}_{4}{ }^{+}$from individual $M$. mercenaria in a laboratory setting where the clams were starved prior to static incubations during which the clams were fed cultured algae. After calculating excretion for the individual clams in each core we summed these rates per core and scaled to per $\mathrm{m}^{2}$ to compare to the net benthic $\mathrm{NH}_{4}{ }^{+}$flux measurements.

\section{Estimating macroalgal growth rate and nitrogen demand}

The importance of benthic nutrient regeneration at the clam beds in meeting the macroalgal $\mathrm{N}$ demand was assessed using estimated macroalgal growth rates and nutrient content in the macroalgal tissue. Macroalgal production rates were not directly measured in this study but were estimated by subtracting the NCP (mmol $\mathrm{C} \mathrm{m}^{-2} \mathrm{~d}^{-1}$ ) of the clam plus macroalgae treatment from the clam only treatment. The average total $\mathrm{N}$ and organic $\mathrm{C}$ content of each macroalgal species retrieved from the cores after the incubations during each season were used to generate a weighted average $\mathrm{N}$ and $\mathrm{C}$ content for the macroalgal community during each sampling month as:

$$
\mathrm{N} \text { or } \mathrm{C} \text { content }=\Sigma W_{i} X_{i}
$$

where $W_{i}$ is equal to the proportion of species $i$ relative to the total macroalgal biomass and $X_{i}$ is equal to the tissue $\mathrm{N}$ or $\mathrm{C}$ content of species $i$ ( $\mathrm{g} \mathrm{C} \mathrm{g}$ $\mathrm{DW}^{-1}$ or $\mathrm{g} \mathrm{N} g \mathrm{DW}^{-1}$ ) . Estimated production rates were converted to growth rates by dividing them by the species-weighted average macroalgal $C$ content. Macroalgal $\mathrm{N}$ demands were then calculated by multiplying growth rate by the species-weighted average $\mathrm{N}$ content of the macroalgal tissue. The following equations summarize our calculations:

$$
\begin{gathered}
\mathrm{MP}=\mathrm{NCP}_{\mathrm{C}}-\mathrm{NCP}_{\mathrm{CM}} \\
\mathrm{MG}=\mathrm{MP} / \mathrm{C} \text { content } \\
\mathrm{MN}=\mathrm{MG} \times \mathrm{N} \text { content } \times(1 \mathrm{~mol} / 14 \mathrm{~g}) \times \\
(1000 \mathrm{mmol} / 1 \mathrm{~mol})
\end{gathered}
$$

where $\mathrm{MP}, \mathrm{MG}$, and $\mathrm{MN}$ refer to macroalgal production rate $\left(\mathrm{g} \mathrm{C} \mathrm{m}^{-2} \mathrm{~d}^{-1}\right)$, growth rate $\left(\mathrm{g} \mathrm{DW} \mathrm{m} \mathrm{m}^{-2} \mathrm{~d}^{-1}\right)$, and $\mathrm{N}$ demand (mmol $\mathrm{N} \mathrm{m}^{-2} \mathrm{~d}^{-1}$ ), respectively; $\mathrm{NCP}_{\mathrm{C}}$ and $\mathrm{NCP}_{\mathrm{CM}}$ are the net community production in the clam only treatment and the clam plus macroalgae treatment ( $\mathrm{g} \mathrm{C} \mathrm{m}^{-2} \mathrm{~d}^{-1}$ ), respectively; and $\mathrm{C}$ content and $\mathrm{N}$ content are the species-weighted average organic $\mathrm{C}$ and total $\mathrm{N}$ of the macroalgal community during each season ( $\mathrm{g} \mathrm{C} \mathrm{g} \mathrm{DW}^{-1}$ or $\mathrm{g} \mathrm{N} \mathrm{g} \mathrm{DW}^{-1}$ ) (see Eq. 7).

\section{Water quality and sediment parameters}

Triplicate sediment cores were collected at each clam and bare flux location seasonally, sub-sectioned horizontally at 0-1 cm and 1-5 cm, and analyzed for porosity (as loss of wet weight after drying at $70^{\circ} \mathrm{C}$ ) and organic matter (as loss on ignition after combustion at $500^{\circ} \mathrm{C}$ for $5 \mathrm{~h}$ ). Dried subsamples were acidified and analyzed on a Carlo Erba (Thermo Electron Flash EA 1112 Series) elemental analyzer for POC and total nitrogen content. Triplicate water column and porewater samples were collected at each flux location, filtered $(0.45 \mu \mathrm{m}$ Whatman polyethersulfone [PES]) and frozen until analysis for DIN $\left(\mathrm{NO}_{3}{ }^{-}, \mathrm{NO}_{2}{ }^{-}\right.$, and $\mathrm{NH}_{4}{ }^{+}$) (Liao 2001, Smith \& Bogren 2001), SRP (Knepel \& Bogren 2001), and DON (Koroleff 1983) on a Lachat QuikChem 8000 automated ion analyzer (Lachat Instruments; detection limits for $\mathrm{NO}_{3}{ }^{-}, \mathrm{NH}_{4}{ }^{+}$, and $\mathrm{PO}_{4}{ }^{3-}$ are $0.20,0.36$, and $0.16 \mu \mathrm{M}$, respectively). Porewater was collected at 5 to $7 \mathrm{~cm}$ below the sediment surface using a stainless steel push-point sampler (MHE Products), and also analyzed for hydrogen sulfide (Cline 1969). Water column samples were filtered $(0.7 \mu \mathrm{m} \mathrm{GF} / \mathrm{F})$ and extracted for chl a and phaeophytin analysis as described by Anderson et al. (2014). Salinity, temperature, DO, chl $a$, and turbidity were monitored continuously throughout each $3 \mathrm{~d}$ experiment using a YSI model 6600 datasonde mounted on a rebar frame, with the sensors $5 \mathrm{~cm}$ above the sediment surface. Incident light and underwater photosynthetically active radiation (PAR) were monitored continuously throughout each $3 \mathrm{~d}$ experiment using a Li-Cor quantum deck sensor (LI-190SA) and underwater quantum sensor (LI-192SA). 


\section{Statistical analysis}

Daily metabolic rates and descriptive measurements (e.g. porewater nutrients, sediment organic matter, etc.) were analyzed using mixed-effect models with season and treatment as independent fixed factors and the location within the farm as a random factor. Effects due to location within the farm could not be distinguished from those due to the day incubations were conducted (e.g. differences in ambient light), however they were not a focus of this study. Post hoc tests were performed using Tukey's HSD. When significant interactions were observed, post hoc tests were conducted to determine differences across seasons within treatments as well as across treatments within seasons. When necessary, data were transformed using Box-Cox to meet assumptions. Linear regressions were used to assess the relationship of clam biomass with $\mathrm{NH}_{4}{ }^{+}$and DIC fluxes. The stoichiometric relationship between $\mathrm{NH}_{4}{ }^{+}$ and DIC fluxes was assessed for each treatment using linear regression, where the $\mathrm{C}: \mathrm{N}$ ratio is equal to the slope of the regression. A significance value of $p<0.05$ was used for all statistical tests, which were conducted in RStudio software (v. 0.98.484).

\section{RESULTS}

\section{Ambient environmental conditions}

Water temperature ranged from $18.5^{\circ} \mathrm{C}$ in October to $29.3^{\circ} \mathrm{C}$ in July, with an intermediate temperature of $20.8^{\circ} \mathrm{C}$ in May. Salinity varied seasonally, increasing from 20.3 in the spring to 25.3 in the fall (Table 1), with no diel tidal variation observed. Water and sediment quality parameters are provided in Table 2 . Water column $\mathrm{NO}_{\mathrm{x}}$ remained low at both the clam and bare sites during all seasons, with no significant effect of site or season. Water column $\mathrm{NH}_{4}{ }^{+}$was slightly higher than $\mathrm{NO}_{\mathrm{x}}$ and was significantly higher at the clam bed sites $(1-2 \mu \mathrm{M})$ than the bare sites $(0.3-1 \mu \mathrm{M})$ despite their close proximity. Porewater DIN, dominated by $\mathrm{NH}_{4}{ }^{+}$, and SRP were signifi-

Table 2. Seasonal sediment and water quality characteristics of the bare and clam sites, including porewater (PW) and water column (WC) nutrients $(\mu \mathrm{M})$, PW sulfide $(\mu \mathrm{M})$, benthic chlorophyll and phaeophytin $\left(\mu \mathrm{g} \mathrm{cm}{ }^{-2}\right)$, sediment organic matter $(\%)$, and sediment organic carbon to total nitrogen ratio $(\mathrm{C}: \mathrm{N})$. Data are means and SE. nd: no data were collected. ${ }^{*}$ Significant difference between treatments within each month (post hoc results, implies significant interactions were observed between month and season). ${ }^{\mp}$ Significant difference between treatments across all months (implies no significant interactions were observed)

\begin{tabular}{|llccr|}
\hline & & May & July & October \\
\hline $\mathrm{PW} \mathrm{NH}_{4}{ }^{+}$ & Bare & $20.95(5.4)^{*}$ & $56.3(6.5)$ & $46.15(4.5)^{*}$ \\
& Clam & $118.7(25.2)$ & $66.1(14.3)$ & $113.2(14.2)$ \\
$\mathrm{WC} \mathrm{NH}_{4}{ }^{+}$ & Bare & $0.31(0.17)$ & $0.56(0.10)$ & $0.94(0.20)$ \\
& Clam & $0.99(0.15)$ & $1.98(0.36)$ & $1.12(0.05)$ \\
$\mathrm{PW} \mathrm{NO}_{x}$ & Bare & $0.75(0.11)$ & $0.34(0.09)$ & $1.16(0.56)$ \\
& Clam & $0.37(0.04)$ & $0.39(0.09)$ & $0.39(0.07)$ \\
$\mathrm{WC} \mathrm{NO}_{\mathrm{x}}$ & Bare${ }^{\mp}$ & $0.24(0.04)$ & $0.12(0.05)$ & $0.11(0.03)$ \\
& Clam & $0.11(0.02)$ & $1.38(1.27)$ & $0.20(0.04)$ \\
$\mathrm{PW} \mathrm{PO}_{4}{ }^{3-}$ & Bare & $1.32(0.39)^{*}$ & $4.12(0.40)$ & $3.02(0.44)^{*}$ \\
& Clam & $8.5(1.25)$ & $5.9(1.53)$ & $7.8(1.23)$ \\
$\mathrm{WC} \mathrm{PO}_{4}{ }^{3-}$ & Bare & $0.06(0.004)$ & $0.08(0.01)^{*}$ & $0.11(0.01)$ \\
& Clam & $0.04(0.004)^{*}$ & $0.15(0.02)$ & $0.11(0.01)$ \\
$\mathrm{PW} \mathrm{sulfide}$ & Bare & nd & $91.9(24.0)$ & $116.9(23.2)$ \\
& Clam & nd & $127.6(13.0)$ & $206.8(63.5)$ \\
Benthic chl a & Bare & $3.50(0.34)$ & $5.62(0.42)$ & $4.78(0.38)$ \\
& Clam & $1.31(0.28)$ & $3.09(0.18)^{*}$ & $3.40(0.13)^{*}$ \\
Benthic & Bare & $1.31(0.11)^{*}$ & $3.09(0.25)^{*}$ & $3.40(0.50)^{*}$ \\
phaeophytin & Clam & $5.53(0.38)$ & $6.98(0.40)$ & $6.75(0.38)$ \\
Sediment OM & Bare & $0.99(0.13)$ & $0.84(0.09)^{*}$ & $0.90(0.11)$ \\
& Clam & $1.09(0.19)$ & $1.87(0.28)$ & $1.02(0.13)$ \\
Sediment C:N & Bare & $7.55(0.37)$ & $7.40(0.17)$ & $7.34(0.16)$ \\
& Clam & $6.63(0.46)$ & $7.39(0.13)$ & $7.03(0.09)$ \\
\hline
\end{tabular}

Table 1. Seasonal site characteristics, clam biomass, density, and shell length observed at the clam beds where flux incubations were conducted. $k_{\mathrm{d} \text { : }}$ light attenuation; PAR: photosynthetically active radiation. Data are means and SE

\begin{tabular}{|lcccccccc|}
\hline Month & Salinity & $\begin{array}{c}\text { Temperature } \\
\left({ }^{\circ} \mathrm{C}\right)\end{array}$ & $\begin{array}{c}\text { Chloro- } \\
\text { phyll } a \\
\left(\mu \mathrm{l} \mathrm{l}^{-1}\right)\end{array}$ & $\begin{array}{c}\text { Dissolved } \\
\text { oxygen } \\
\left(\mathrm{mg} \mathrm{l}^{-1}\right)\end{array}$ & $\begin{array}{c}k_{\mathrm{d}} \\
\left(\mathrm{PAR} \mathrm{m}{ }^{-1}\right)\end{array}$ & $\begin{array}{c}\text { Clam biomass } \\
(\mathrm{g} \text { ash-free } \\
\left.\text { DW m }^{-2}\right)\end{array}$ & $\begin{array}{c}\text { Clam } \\
\text { density } \\
\left(\mathrm{ind}^{-2} \mathrm{~m}^{-2}\right)\end{array}$ & $\begin{array}{c}\text { Clam size } \\
(\text { shell length, } \\
\mathrm{mm}\end{array}$ \\
\hline May & $20.3(0.03)$ & $20.8(0.08)$ & $5.19(0.09)$ & $8.42(0.11)$ & $1.48(0.03)$ & $242.9(19.0)$ & $821(82.5)$ & $40.3(0.3)$ \\
July & $22.2(0.05)$ & $29.3(0.13)$ & $4.41(0.08)$ & $7.18(0.16)$ & $2.16(0.09)$ & $228.9(16.6)$ & $790(47.7)$ & $39.8(0.4)$ \\
October & $25.3(0.01)$ & $18.5(0.06)$ & $2.05(0.07)$ & $8.19(0.05)$ & $1.43(0.03)$ & $319.27(18.8)$ & $999(70.5)$ & $40.4(0.3)$ \\
\hline
\end{tabular}


cantly higher at the clam bed sites compared to the bare sediments in May and October, with no significant differences in July. Although not significant and highly variable, porewater sulfide concentrations tended to be higher at the clam beds than the bare sites. The sediment organic matter content and $\mathrm{C}: \mathrm{N}$ were similar between the clam and bare sediments.

\section{Clam and macroalgal biomass}

The experimental design controlled for clam size by targeting locations within the lease with clams close to market size. Average $( \pm \mathrm{SD})$ shell length was $39.1 \pm 6.2 \mathrm{~mm}$; clam biomass averaged $263.7 \pm$ $103.1 \mathrm{~g}$ ash-free DW $\mathrm{m}^{-2}$, with no significant difference in size across seasons or treatments (Table 1). However, clam beds sampled in October had significantly higher clam biomass than the other months, due to higher densities as opposed to larger individuals (Table $1, \mathrm{p}<0.05$ ).

Typically dominated by Gracilaria spp., macroalgal biomass was highest in July $\left(123.8 \pm 14.9 \mathrm{~g} \mathrm{DW} \mathrm{m}^{-2}\right)$ with the lowest biomass in May $\left(24.1 \pm 9.5 \mathrm{~g} \mathrm{DW} \mathrm{m}^{-2}\right)$ and a biomass of $52.8 \pm 11.9 \mathrm{~g} \mathrm{DW} \mathrm{m}^{-2}$ in October (Table 3). Macroalgal biomass varied seasonally but was also likely influenced by the frequency at which the aquaculturists swept the nets. The effects of sweeping on macroalgal biomass and sediment biogeochemistry were not a focus of this study.

\section{Nutrient fluxes}

Net daily fluxes are shown in Fig. 2. Net $\mathrm{NH}_{4}{ }^{+}$ efflux was observed for all treatments during all months except in the bare treatment (B) in July (Fig. 2A). $\mathrm{NH}_{4}{ }^{+}$fluxes were significantly affected by season and treatment as indicated by the significant interaction term (Table 4). Clam beds $(\mathrm{Cl})$ had significantly higher net $\mathrm{NH}_{4}{ }^{+}$efflux rates, ranging from 13.5 to $18.6 \mathrm{mmol} \mathrm{N} \mathrm{m}{ }^{-2} \mathrm{~d}^{-1}$, than $\mathrm{B}$ (-0.38 to $0.16 \mathrm{mmol} \mathrm{N} \mathrm{m} \mathrm{N}^{-2} \mathrm{~d}^{-1}$ ) during all months. The presence of macroalgae resulted in decreases of $32 \%$, $77 \%$, and $20 \%$ in daily $\mathrm{NH}_{4}{ }^{+}$effluxes at the clam beds in May, July, and October, respectively; with effluxes in May and July in CM significantly lower than in $\mathrm{Cl}$. When macroalgal biomass was highest (July), the $\mathrm{NH}_{4}{ }^{+}$efflux in $\mathrm{CM}\left(4.1 \mathrm{mmol} \mathrm{N} \mathrm{m}{ }^{-2}\right.$ $\mathrm{d}^{-1}$ ) was significantly lower compared with May (12.6 $\left.\mathrm{mmol} \mathrm{N} \mathrm{m}^{-2} \mathrm{~d}^{-1}\right)$ and October $\left(10.7 \mathrm{mmol} \mathrm{N} \mathrm{m}^{-2}\right.$ $\left.\mathrm{d}^{-1}\right)$. $\mathrm{NH}_{4}{ }^{+}$effluxes in $\mathrm{CM}$ were significantly higher than in $\mathrm{B}$, with average fluxes of 16.6 and $-0.06 \mathrm{mmol}$ $\mathrm{N} \mathrm{m}^{-2} \mathrm{~d}^{-1}$, respectively.

Generally, $\mathrm{NO}_{\mathrm{x}}$ fluxes were variable but typically low and positive at all sites during all seasons (Fig. 2B). $\mathrm{NO}_{\mathrm{x}}$ fluxes were affected by treatment and season, as indicated by the significant interaction (Table 4). Within season, there was no significant treatment effect in July, while in May, B had significantly higher $\mathrm{NO}_{\mathrm{x}}$ rates than $\mathrm{CM}$ and in October $\mathrm{B}$ had significantly lower $\mathrm{NO}_{\mathrm{x}}$ rates than both $\mathrm{Cl}$ and $\mathrm{CM}$. Within treatments, no significant seasonal effect was observed in either the $\mathrm{Cl}$ or $\mathrm{CM}$ treatments with average net $\mathrm{NO}_{\mathrm{x}}$ rates of $170 \mu \mathrm{mol} \mathrm{N} \mathrm{m} \mathrm{N}^{-1}$ and $160 \mu \mathrm{mol} \mathrm{N} \mathrm{m}{ }^{-2} \mathrm{~d}^{-1}$, respectively. The B treatment had significantly lower $\mathrm{NO}_{\mathrm{x}}$ flux rates in October (-64 umol $\mathrm{N} \mathrm{m}^{-2} \mathrm{~d}^{-1}$ ) compared with B sites in May and July.

The clam beds and bare sediments typically released DON to the water column (Fig. 2C). Treatment and month had significant effects on DON fluxes, with a significant interaction (Table 4). There was no dif-

Table 3. Mean biomass ( $\mathrm{g} \mathrm{DW} \mathrm{m}^{-2}$ ) and SE of macroalgae by species retrieved from the clams plus macroalgae in the light $(\mathrm{CML})$ and dark (CMD) cores after the incubations during each season. The species within the experimental cores reflects the ambient species composition found in situ each month. Also shown is the mean percent total $\mathrm{N}$ and organic $\mathrm{C}$ content of each species per month. nd: no data; (-) not applicable. 'Other' species in May were predominately Cladophora sp.

\begin{tabular}{|c|c|c|c|c|c|c|c|c|c|}
\hline & \multirow[b]{2}{*}{ Biomass } & \multirow{2}{*}{$\begin{array}{l}\text { May } \\
\% \mathrm{~N}\end{array}$} & \multirow[b]{2}{*}{$\% \mathrm{C}$} & \multirow[b]{2}{*}{ Biomass } & \multirow{2}{*}{$\begin{array}{l}\text { July } \\
\% \text { N }\end{array}$} & \multirow[b]{2}{*}{$\% \mathrm{C}$} & \multirow[b]{2}{*}{ Biomass } & \multirow{2}{*}{$\begin{array}{c}\text { October } \\
\% \mathrm{~N}\end{array}$} & \multirow[b]{2}{*}{$\% \mathrm{C}$} \\
\hline & & & & & & & & & \\
\hline Ulva lactuca & $0.52(0.2)$ & $2.44(0.43)$ & $27.08(2.5)$ & $1.54(0.5)$ & nd & nd & 0 & - & - \\
\hline Gracilaria spp. & $10.35(2.0)$ & $1.51(0.04)$ & $27.84(0.9)$ & $84.1(6.8)$ & $3.40(0.3)$ & $33.96(2.3)$ & $41.1(4.9)$ & $3.53(0.3)$ & $34.61(1.5)$ \\
\hline Agardhiella & 0 & - & - & $38.17(6.7)$ & $2.80(0.2)$ & $28.28(0.8)$ & $8.88(2.9)$ & $2.76(0.4)$ & $29.42(1.1)$ \\
\hline Other & $0.57(0.1)$ & nd & nd & 0 & - & - & 0 & - & - \\
\hline Total biomass & $24.13(2.3)$ & - & - & $123.8(3.5)$ & - & - & $52.8(2.8)$ & - & - \\
\hline $\begin{array}{l}\text { Species-weighted } \\
\text { mean of macro- } \\
\text { algal community }\end{array}$ & - & 2.02 & 27.32 & - & 3.22 & 32.19 & - & 3.39 & 33.69 \\
\hline
\end{tabular}


A

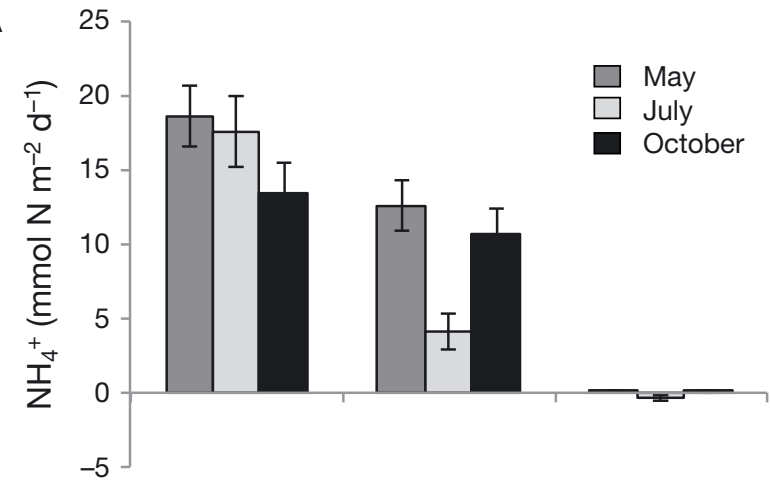

C

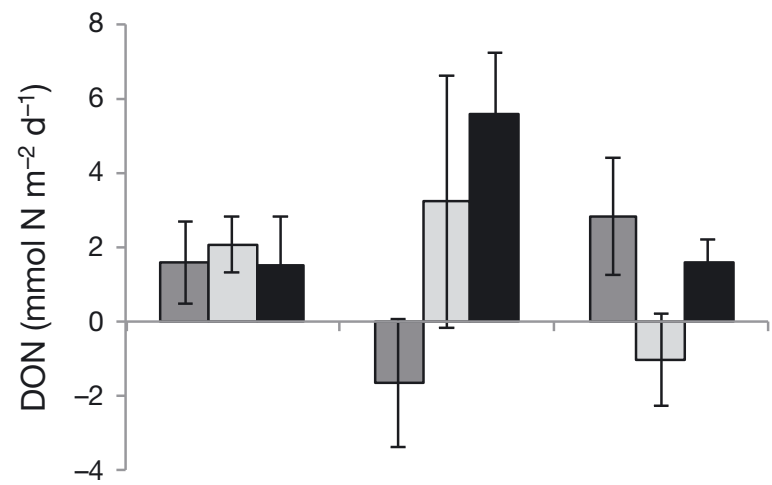

E

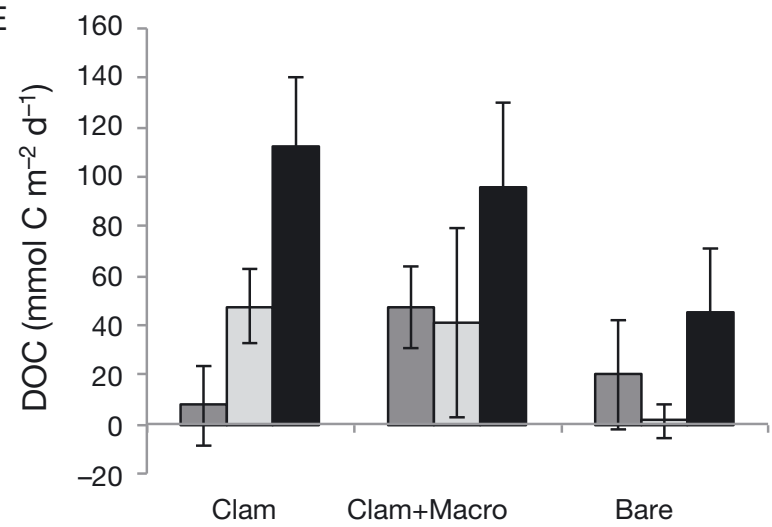

B

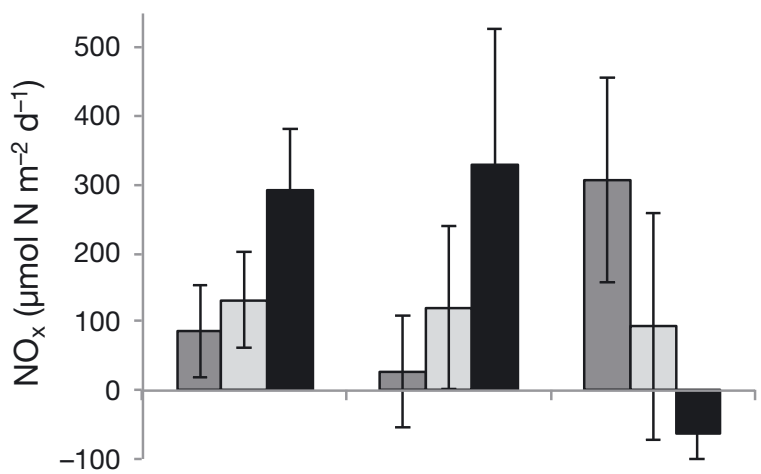

D

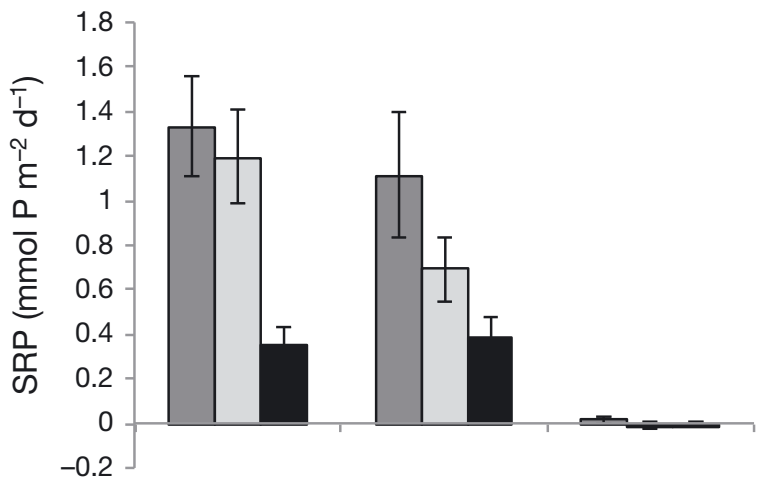

F

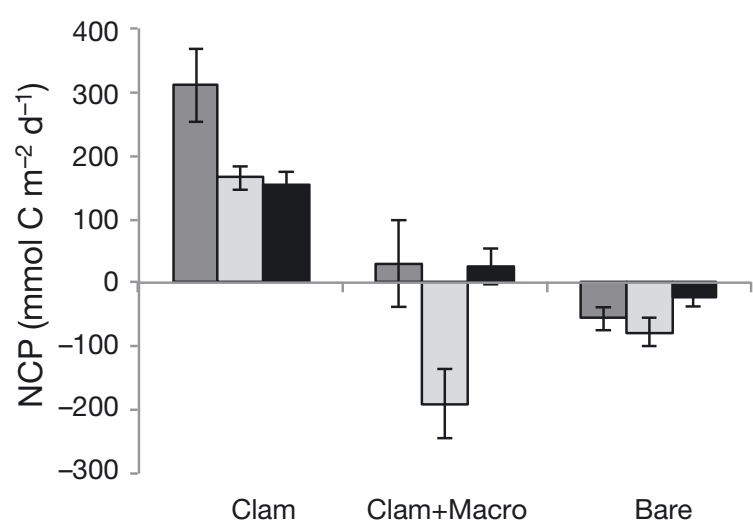

Fig. 2. (A) Net daily flux rates of ammonium $\left(\mathrm{NH}_{4}^{+}\right)^{+}$, (B) nitrate + nitrite $\left(\mathrm{NO}_{\mathrm{x}}\right),(\mathrm{C})$ dissolved organic nitrogen (DON), (D) soluble reactive phosphorous (SRP), (E) dissolved organic carbon (DOC), and (F) net benthic community production (NCP), calculated using DIC fluxes, for all treatments including clam only (Clam), clam plus macroalgae (Clam+Macro), and control sediment (Bare), in May, July, and October 2012. Data are mean $\pm \mathrm{SE}$

ference across treatments in July or October. However, in May the DON flux in $\mathrm{B}\left(2.8 \mathrm{mmol} \mathrm{N} \mathrm{m}^{-2} \mathrm{~d}^{-1}\right)$ was significantly higher than in $\mathrm{CM}\left(-1.7 \mathrm{mmol} \mathrm{N} \mathrm{m}^{-2}\right.$ $\mathrm{d}^{-1}$ ). Within the $\mathrm{B}$ and $\mathrm{Cl}$ treatments, there was no effect of season. Within the CM treatment, May had significantly lower values than October, while July values were not different from those in May or October.

Net effluxes of SRP in the $\mathrm{Cl}$ and CM treatments were significantly greater than in B during all sea- sons (Fig. 2D). However, the presence of macroalgae had no significant effect on the clam bed SRP flux. Seasonal trends were detected in the $\mathrm{Cl}$ and $\mathrm{CM}$ treatments with a significantly lower net SRP efflux in October, averaging $369.3 \mu \mathrm{mol} \mathrm{P} \mathrm{m}{ }^{-2} \mathrm{~d}^{-1}$ compared with May and July, which averaged 1221.7 and $943.8 \mu \mathrm{mol} \mathrm{P} \mathrm{m}{ }^{-2} \mathrm{~d}^{-1}$, respectively. The B treatment, which showed no seasonal variation, had negligible SRP flux rates. 
Table 4. Statistical parameters from the mixed-effect models with treatment and month as fixed factors and day sampled as the random factor on daily flux rates. $\mathrm{n}=9$ for each treatment per month; treatments were sampled over 3 consecutive days. Summaries of the post hoc test results are provided when a significant interaction was observed. NO $\mathrm{N}_{\mathrm{x}}$ nitrate + nitrite; DON: dissolved organic nitrogen; SRP: soluble reactive phosphorous; DOC: dissolved organic carbon; NCP: net community production. Months - M: May; J: July; O: October. Treatments — B: bare, Cl: clam only; CM: clam plus macroalgae. ns: no significant difference among groups

\begin{tabular}{|c|c|c|c|c|c|c|}
\hline \multirow[t]{2}{*}{ Response } & \multirow[t]{2}{*}{ Factors } & \multirow[t]{2}{*}{$F$} & \multirow[t]{2}{*}{$\mathrm{df}$} & \multirow[t]{2}{*}{$\mathrm{p}$} & \multicolumn{2}{|c|}{ — Post hoc summary } \\
\hline & & & & & Month within treatment & Treatment within month \\
\hline \multirow[t]{3}{*}{$\mathrm{NH}_{4}^{+}$} & Treatment & 220.99 & 2 & $<0.001$ & $\mathrm{Cl}: \mathrm{ns}$ & May: $\mathrm{B}<\mathrm{CM}<\mathrm{Cl}$ \\
\hline & Month & 5.47 & 2 & 0.044 & CM: $\mathrm{J}<\mathrm{M}=\mathrm{O}$ & July: $\mathrm{B}<\mathrm{CM}<\mathrm{Cl}$ \\
\hline & Treatment $\times$ Month & 5.17 & 4 & 0.001 & B: ns & Oct: $\mathrm{B}<\mathrm{CM}=\mathrm{Cl}$ \\
\hline \multirow[t]{3}{*}{$\mathrm{NO}_{\mathrm{x}}$} & Treatment & 0.60 & 2 & 0.55 & $\mathrm{Cl}: \mathrm{ns}$ & May: B > CM \\
\hline & Month & 0.13 & 2 & 0.88 & $\mathrm{CM}: \mathrm{J}<\mathrm{M}=\mathrm{O}$ & July: ns \\
\hline & Treatment $\times$ Month & 4.07 & 4 & 0.005 & B: ns & Oct: $\mathrm{B}<\mathrm{Cl}=\mathrm{CM}$ \\
\hline \multirow[t]{3}{*}{ DON } & Treatment & 0.45 & 2 & 0.64 & $\mathrm{Cl}: \mathrm{ns}$ & May: B > CM \\
\hline & Month & 0.76 & 2 & 0.51 & $\mathrm{CM}: \mathrm{M}<\mathrm{O}$ & July: ns \\
\hline & Treatment $\times$ Month & 4.42 & 4 & 0.003 & $\mathrm{~B}: \mathrm{ns}$ & Oct: ns \\
\hline \multirow[t]{3}{*}{ SRP } & Treatment & 122.40 & 2 & $<0.001$ & $\mathrm{Cl}: \mathrm{J}=\mathrm{M}>\mathrm{O}$ & May: $\mathrm{B}<\mathrm{Cl}=\mathrm{CM}$ \\
\hline & Month & 4.17 & 2 & 0.07 & $\mathrm{CM}: \mathrm{M}>\mathrm{O}$ & July: $\mathrm{B}<\mathrm{Cl}=\mathrm{CM}$ \\
\hline & Treatment $\times$ Month & 4.67 & 4 & 0.002 & $\mathrm{~B}: \mathrm{ns}$ & Oct: $\mathrm{B}<\mathrm{Cl}=\mathrm{CM}$ \\
\hline \multirow[t]{3}{*}{ DOC } & Treatment & 2.77 & 2 & 0.07 & & \\
\hline & Month & 2.86 & 2 & 0.13 & & \\
\hline & Treatment $\times$ Month & 1.36 & 4 & 0.26 & & \\
\hline \multirow[t]{3}{*}{$\mathrm{NCP}$} & Treatment & 52.60 & 2 & $<0.001$ & $\mathrm{Cl}: \mathrm{J}=\mathrm{O}<\mathrm{M}$ & May: $\mathrm{B}=\mathrm{CM}<\mathrm{Cl}$ \\
\hline & Month & 6.30 & 2 & 0.033 & $\mathrm{CM}: \mathrm{J}<\mathrm{M}=\mathrm{O}$ & July: $\mathrm{B}=\mathrm{CM}<\mathrm{Cl}$ \\
\hline & Treatment $\times$ Month & 4.50 & 4 & 0.003 & B: ns & Oct: $\mathrm{B}=\mathrm{CM}<\mathrm{Cl}$ \\
\hline
\end{tabular}

DOC was typically released from sediments at all treatments and during all sampling months (Fig. 2E). There was no significant effect of season or treatment on DOC fluxes, and no significant interaction (Table 4). DOC effluxes were generally higher in the clam treatments compared to the bare sediments, although not significantly.

\section{Benthic metabolism}

$\mathrm{NCP}$ in the $\mathrm{Cl}$ treatment was net heterotrophic during all sampling months and significantly different from the net autotrophic bare sediment sites (Fig. 2F). The presence of macroalgae significantly decreased $\mathrm{NCP}$ at the clam beds during all sampling months, shifting it towards net autotrophy, which in our calculations is represented by a negative value. The $\mathrm{NCP}$ in the CM treatment was not significantly different than the B treatment. Therefore, the presence of macroalgae negated the influence of clams on the net benthic metabolism. No seasonal variation in B was observed, with an average NCP of $-51.0 \mathrm{mmol} \mathrm{C}$ $\mathrm{m}^{-2} \mathrm{~d}^{-1}$. The $\mathrm{Cl}$ treatment was significantly more heterotrophic in May (311.2 $\mathrm{mmol} \mathrm{C} \mathrm{m}^{-2} \mathrm{~d}^{-1}$ ) than July and October, which averaged $159.3 \mathrm{mmol} \mathrm{C} \mathrm{m}^{-2} \mathrm{~d}^{-1}$. The CM treatment was slightly net heterotrophic during May and October (average of $28 \mathrm{mmol} \mathrm{C} \mathrm{m}^{-2}$ $\left.\mathrm{d}^{-1}\right)$ and shifted to net autotrophic in July $(-190 \mathrm{mmol}$ $\mathrm{C} \mathrm{m}^{-2} \mathrm{~d}^{-1}$ ). Similar to the $\mathrm{NH}_{4}{ }^{+}$flux, the seasonal NCP trends observed in the CM treatment were likely a result of higher macroalgal biomass added to the cores in the summer, when macroalgal standing stock biomass was highest on the nets (Table 3).

\section{Variation of $\mathrm{NH}_{4}{ }^{+}$and DIC fluxes with clam biomass}

Estimated mean $\pm \mathrm{SD}$ clam $\mathrm{NH}_{4}{ }^{+}$excretion rates (using the equation from Sma \& Baggaley 1976) ranged from $233.6 \pm 66.6 \mu \mathrm{mol} \mathrm{N} \mathrm{m}{ }^{-2} \mathrm{~h}^{-1}$ in July to $542.8 \pm 225.0 \mu \mathrm{mol} \mathrm{N} \mathrm{m}{ }^{-2} \mathrm{~h}^{-1}$ in May and an intermediate of $410.5 \pm 136.2 \mu \mathrm{mol} \mathrm{N} \mathrm{m}{ }^{-2} \mathrm{~h}^{-1}$ in October. Estimated clam excretion accounted for an average of 66 , 40 , and $83 \%$ of the hourly flux rates of $\mathrm{NH}_{4}{ }^{+}$in the clam only treatments in May, July, and October, respectively.

When all 3 seasons were analyzed together, $\mathrm{NH}_{4}{ }^{+}$ and DIC fluxes were positively correlated with clam biomass (ash-free DW core $\left.{ }^{-1}\right)\left(\mathrm{p}=0.001, \mathrm{R}^{2}=0.15 ; \mathrm{p}=\right.$ $0.004, R^{2}=0.16$, respectively) and DO fluxes were negatively correlated with clam biomass $(p=0.005$, $\mathrm{R}^{2}=0.15$ ) (Fig. 3, Table 5). However, in July, $\mathrm{NH}_{4}{ }^{+}$, 

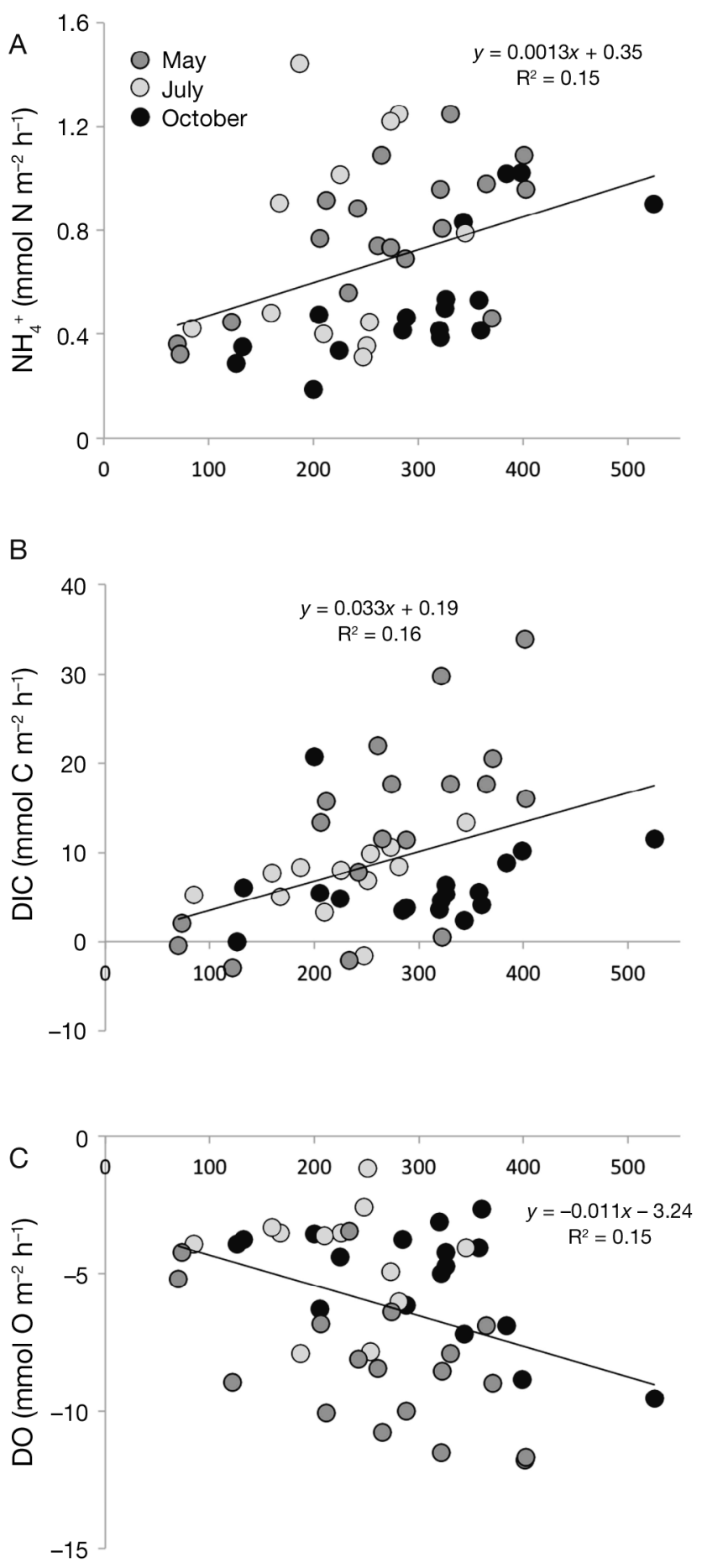

Clam biomass (ash-free DW $\mathrm{g} \mathrm{m}^{-2}$ )

Fig. 3. (A) Hourly (light and dark) ammonium $\left(\mathrm{NH}_{4}{ }^{+}\right)$, (B) dissolved inorganic carbon (DIC), and (C) dissolved oxygen (DO) fluxes as a function of clam biomass (ash-free DW g $\mathrm{m}^{-2}$ ), in May, July, and October 2012. Analyses included clam dark and clam light treatments only. The solid line is the regression including all months. Slopes and regression statistics are provided in Table 5
Table 5. Regression statistics of hourly fluxes of ammonium $\left(\mathrm{NH}_{4}{ }^{+}\right)$, dissolved inorganic carbon (DIC), and dissolved oxygen (DO) as a function of clam biomass ( $g$ ash-free $\mathrm{DW} \mathrm{m}^{-2}$ ). Only clam treatments (light and dark) were included in the analyses. Fig. 3 provides graphical representation of the data. Significant results $(p<0.05)$ in bold

\begin{tabular}{|lcccc|}
\hline Parameter & Month & Slope & $\mathrm{R}^{2}$ & $\mathrm{p}$ \\
\hline $\mathrm{NH}_{4}{ }^{+}$ & May & 0.002 & 0.42 & $\mathbf{0 . 0 0 2}$ \\
& July & 0.001 & 0.04 & 0.533 \\
& October & 0.002 & 0.52 & $<\mathbf{0 . 0 0 1}$ \\
DIC & All & 0.001 & 0.15 & $\mathbf{0 . 0 0 8}$ \\
& May & 0.071 & 0.44 & $\mathbf{0 . 0 0 2}$ \\
& July & 0.024 & 0.10 & 0.16 \\
DO & October & 0.008 & 0.03 & 0.52 \\
& All & 0.033 & 0.16 & $\mathbf{0 . 0 0 5}$ \\
& May & -0.014 & 0.31 & $\mathbf{0 . 0 1 0}$ \\
& July & -0.002 & 0.01 & 0.822 \\
& October & -0.011 & 0.29 & $\mathbf{0 . 0 1 5}$ \\
& All & -0.011 & 0.15 & $\mathbf{0 . 0 0 7}$ \\
\hline
\end{tabular}

DIC, and DO fluxes were not significantly correlated with clam biomass. Additionally, in October, DIC flux was not significantly correlated with clam biomass. Notably, clam biomass varied little across samples, as beds were planted at relatively constant densities and only sites with clams close to market size were sampled.

\section{Flux stoichiometry}

The ratio between DIC and $\mathrm{NH}_{4}{ }^{+}$fluxes is a metric used to infer the characteristics and fate of the organic matter being remineralized as well as the relative importance of phototrophic and denitrifying activity. A low C: $\mathrm{N}$ ratio may indicate high $\mathrm{N}$ release and/or the remineralization of highly labile organic matter, with a low C:N signature. A high C:N ratio suggests denitrification and/or $\mathrm{N}$ immobilization by phototrophic and/or bacterial uptake. Linear regression analyses of DIC fluxes as a function of $\mathrm{NH}_{4}{ }^{+}$ fluxes were used to obtain $\mathrm{C}: \mathrm{N}$ of the fluxes for each treatment (i.e. $\mathrm{C}: \mathrm{N}=$ the slope). $\mathrm{C}: \mathrm{N}$ at the clam bed (9.9) was lower than in the clam with macroalgae (23.7) and bare treatments (66.1) (Table 6). In the light, C:N increased in clam treatments with and without macroalgae. However, $\mathrm{C}: \mathrm{N}$ was higher in the dark than in the light at the bare sites.

\section{Macroalgal growth rate and nitrogen demand}

Estimated macroalgal production rates were 3.38, 4.26, and $1.53 \mathrm{~g} \mathrm{C} \mathrm{m}^{-2} \mathrm{~d}^{-1}$ in May, July, and October, 
Table 6. Linear regression estimates of the relative proportion (slope) of dissolved inorganic carbon to ammonium fluxes on a net daily basis, as well as in the dark and in the light for all treatments: clam only $(\mathrm{Cl})$, clam plus macroalgae $(\mathrm{CM})$, and control sediment (B). Significant results $(\mathrm{p}<0.05)$ in bold

\begin{tabular}{|ccrcr|}
\hline & Treatment & Slope & $\mathrm{R}^{2}$ & $\mathrm{p}$-value \\
\hline Daily & $\mathrm{Cl}$ & 9.9 & 0.23 & $\mathbf{0 . 0 0 7}$ \\
& $\mathrm{CM}$ & 23.7 & 0.56 & $\mathbf{0 . 0 0 0}$ \\
& $\mathrm{B}$ & 66.1 & 0.16 & $\mathbf{0 . 0 2 2}$ \\
Dark & $\mathrm{Cl}$ & 8.3 & 0.07 & 0.098 \\
& $\mathrm{CM}$ & 10.3 & 0.29 & $\mathbf{0 . 0 0 2}$ \\
& $\mathrm{B}$ & 39.9 & 0.10 & 0.062 \\
Light & $\mathrm{Cl}$ & 13.1 & 0.27 & $\mathbf{0 . 0 0 3}$ \\
& $\mathrm{CM}$ & 30.1 & 0.47 & $\mathbf{0 . 0 0 0}$ \\
& $\mathrm{B}$ & 26.7 & -0.02 & 0.466 \\
\hline
\end{tabular}

respectively. Using the species-weighted average percent carbon of the macroalgal tissue collected from the cores after the incubations each month (Table 3), macroalgal growth rates were estimated to be 12.36 , 13.24, and $4.56 \mathrm{~g} \mathrm{DW} \mathrm{m}^{-2} \mathrm{~d}^{-1}$ in May, July, and October, respectively. Macroalgal $\mathrm{N}$ demands were estimated as 17.84, 30.42, and $11.04 \mathrm{mmol} \mathrm{N} \mathrm{m}^{-2} \mathrm{~d}^{-1}$ in May, July, and October, respectively. The sediment $\mathrm{NH}_{4}{ }^{+}$fluxes as percent of macroalgal $\mathrm{N}$ demand in May, July, and October were 105\%, 58\%, and 122\%, respectively.

\section{DISCUSSION}

Although clam aquaculture is a growing industry worldwide, there are currently few studies on its effects on nutrient cycling and subsequent influences on autotrophic production (reviewed in Burkholder \& Shumway 2011). Clam aquaculture sediments are sites of high metabolic activity, significantly enhancing nutrient release to the water column while drawing down DO. Bivalve aquaculture does not require organic matter addition (i.e. feed) and is therefore a bio-extractive activity and overall a net nutrient sink. However, our data suggest high densities of bivalves significantly alter local nutrient supply and enhance macroalgal production (Fig. 4). The macroalgae serve an important ecological function in temporarily sequestering nutrients released from the cultivated clam beds. But without proper management, this increased organic matter may lead to adverse conditions in the estuary; upon senescence, microbial degradation of the macroalgae may decrease oxygen and release nutrients. Implementing macroalgal harvest practices concurrent with clam harvest (i.e. an integrated multi-trophic aquaculture [IMTA] program) would eliminate the potentially detrimental impacts of excess macroalgal material in the system.

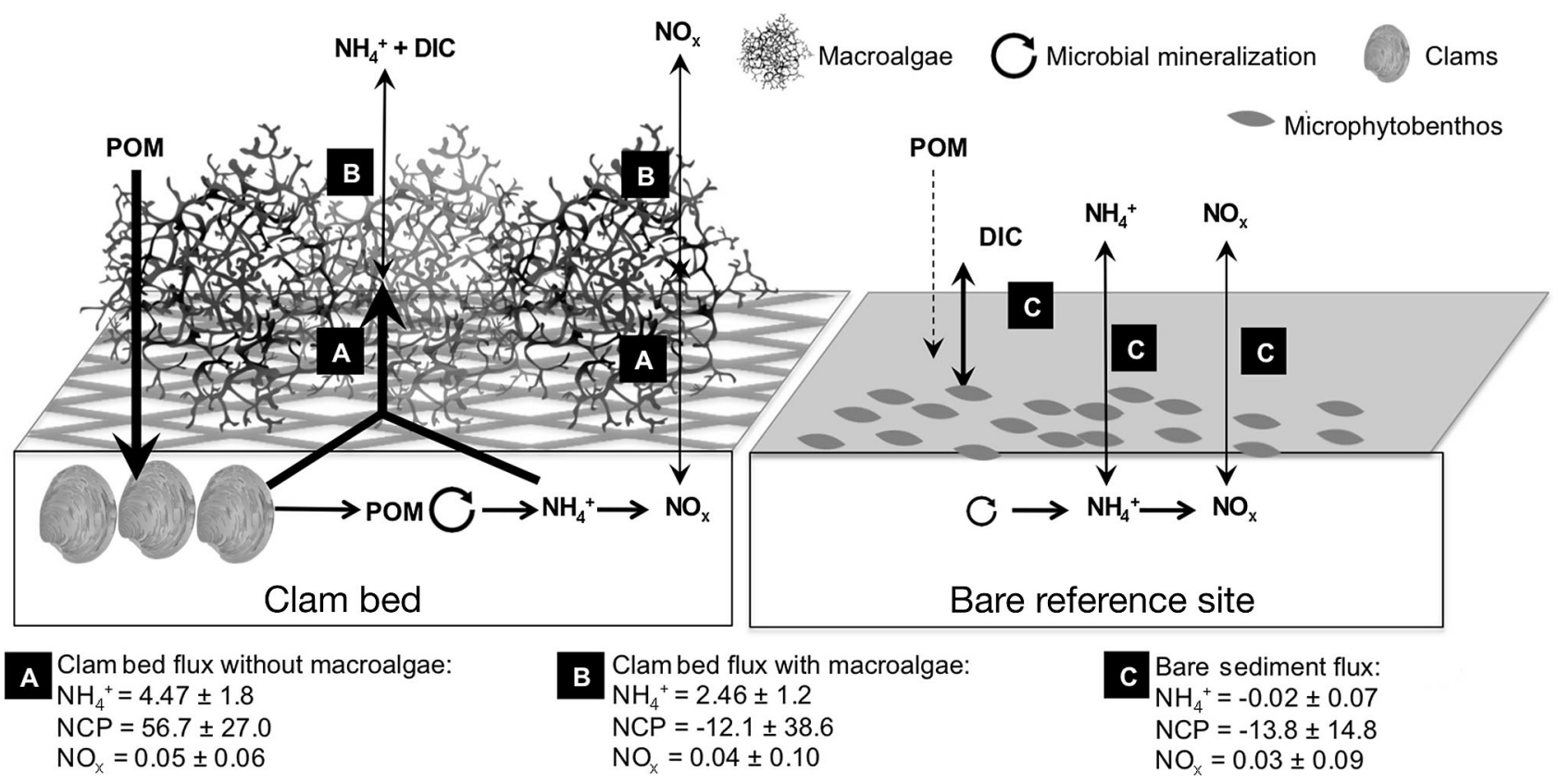

Fig. 4. A conceptual model illustrating the net annual fluxes of $\mathrm{NH}_{4}{ }^{+}, \mathrm{NO}_{\mathrm{x}}\left(\mathrm{mol} \mathrm{N} \mathrm{m}^{-2} \mathrm{yr}^{-1}\right)$ and net community production $\left(\mathrm{NCP} ; \mathrm{mol} \mathrm{C} \mathrm{m} \mathrm{yr}^{-1}\right)$; a positive flux represents net heterotrophy; a negative flux net autotrophy. POM: particulate organic matter; $\mathrm{NH}_{4}{ }^{+}$: ammonium; $\mathrm{NO}_{\mathrm{x}}$ : nitrate + nitrite; DIC: dissolved inorganic carbon 


\section{Cultivated clam beds alter benthic metabolism and nutrient supply}

Clams directly alter the local environment through their respiration and excretion. We estimated clam excretion to account for between 40 and $83 \%$ of the total $\mathrm{NH}_{4}{ }^{+}$efflux at the clam beds. Others have similarly observed that bivalve excretion can significantly increase net sediment nutrient effluxes (Magni et al. 2000, Hiwatari et al. 2002, Gibbs et al. 2005). Despite high excretion rates, the clam beds did not alter DON fluxes relative to bare sediments - likely because the majority of $M$. mercenaria excretion is DIN rather than DON (Hammen 1980). Clam respiration is a large component of benthic community metabolism as clam biomass was significantly correlated with DO and DIC fluxes when data from all sampling months were grouped. However, in the summer and fall, anaerobic microbial respiration was likely driving DIC fluxes, as these fluxes were not tightly coupled to clam biomass. Additionally, DO fluxes in the summer were not strongly correlated with clam biomass, which may be due to the narrow range in biomass sampled as only market-size clam beds were targeted in this study and cultivated clams are planted at relatively constant densities. Despite high respiration rates, clam beds did not contribute to hypoxic conditions in the water column; nighttime DO at the clam beds was only slightly lower than concentrations observed at the control sites (see the Appendix).

Clams indirectly affect benthic nutrient fluxes and respiration by fueling microbial mineralization of biodeposits. Increased nutrient effluxes and sediment oxygen demand have been attributed to bivalves enriching sediments with biodeposits (e.g. Nizzoli et al. 2006, Smyth et al. 2013). The bulk sediment organic C to total $\mathrm{N}$ ratio in Cherrystone Inlet is relatively low (6.6-7.6) compared to nearby systems such as Hog Island Bay, Virginia, which averages 13.3 (Anderson et al. 2003). In Cherrystone Inlet the low sediment $\mathrm{C}: \mathrm{N}$ is likely due to delivery of N-rich, phytoplankton-derived clam biodeposits to the sediments. Bivalve biodeposits are typically labile and readily remineralized in sediments (Giles \& Pilditch 2006, Carlsson et al. 2010). Although biodeposit mineralization can cause decreased DO and sulfide accumulation in the porewater, clam bioturbation can oxygenate the sediments, increasing rates of nutrient transformations and transport across the sediment-water interface (Aller 1982, Kristensen \& Blackburn 1987, Kristensen 2000). However, in an aquaculture setting, high clam densities and the predator exclusion net may constrict clam movement and decrease bioturbation.
At our sites, clam aquaculture decreased the relative proportion of DIC to $\mathrm{NH}_{4}{ }^{+}$fluxes compared to uncultivated bare sites, further highlighting that clam beds are a source of regenerated nutrients to the water column. At the net autotrophic bare sites, the high DIC: $\mathrm{NH}_{4}{ }^{+}$of the fluxes and increased uptake of $\mathrm{N}$ in the light versus dark incubations indicates $\mathrm{N}$ immobilization in the benthos by microphytobenthos (MPB); alternatively, $\mathrm{N}$ may be removed by denitrification. At the clam beds, low DIC release relative to $\mathrm{NH}_{4}{ }^{+}$reflects the high rate of $\mathrm{N}$ recycling in the benthos and suggests low rates of denitrification and/or a lack of MPB uptake. High sulfide accumulation in the clam bed porewater may inhibit nitrification coupled to denitrification (Joye \& Hollibaugh 1995), further enhancing $\mathrm{NH}_{4}{ }^{+}$release to the water column. However, release of $\mathrm{NO}_{\mathrm{x}}$, albeit at low rates, at both the clam and bare sites suggests that nitrification may be occurring at low rates. Another potential source of $\mathrm{NO}_{\mathrm{x}}$ at the clam beds is subterranean groundwater discharge through the sandy sediments (Reay et al. 1992, Stanhope et al. 2009), which is included in this in situ experiment. Benthic chlorophyll, typically lower at the clam beds than the bare sites, suggests less MPB, potentially due to shading by the nets and macroalgal mats or due to increased grazing by clams under the nets (Sauriau \& Kang 2000, Cognie et al. 2001, Secrist 2013). When macroalgae were included at the clam beds, the DIC: $\mathrm{NH}_{4}{ }^{+}$of the fluxes increased to 23.7, with a higher ratio in the light compared to the dark, indicating the significant role macroalgae play in modulating $\mathrm{N}$ released from the clam beds.

\section{Cultivated clam beds support macroalgal production}

The dominant macroalgae on clam nets in Cherrystone Inlet, the ephemeral, opportunistic Gracilaria spp., have a high capacity to intercept nutrients sourced from the clam sediments: benthic $\mathrm{NH}_{4}{ }^{+}$ efflux was reduced by $20-77 \%$ and SRP efflux by up to $43 \%$. Other studies have similarly reported that macroalgae effectively assimilate nutrients fluxing from sediments, temporarily sequestering them in their tissue (i.e. McGlathery et al. 1997, Sundbäck et al. 2003, Hardison et al. 2011). As macroalgae are not long-lived, this nutrient storage is only temporary and macroalgal biomass rapidly decays upon senescence, releasing inorganic and organic nutrients back to the water column (Tyler et al. 2001, Hardison et al. 2010). 
By enhancing nutrient recycling, clam beds in Cherrystone Inlet serve as an important internal source of nutrients to primary producers within the system. Others have similarly found bivalves to greatly influence the availability of sediment-derived nutrients to benthic and pelagic producers (Doering et al. 1986, Asmus \& Asmus 1991, Giles \& Pilditch 2006). In natural clam-dominated systems, nutrient fluxes from $M$. mercenaria beds can exceed phytoplankton net demand for N and P (Murphy \& Kremer 1985). In Cherrystone Inlet, we found that the clam aquaculture sediments provided 58 to $122 \%$ of the macroalgal $\mathrm{N}$ demand. The percent of macroalgal $\mathrm{N}$ demand supplied by the benthos exceeds estimates reported in nearby systems (27 to $75 \%$; Tyler et al. 2003), which rely more on external nutrient loading.

The relative importance of clam aquaculture as an internal nutrient source to the system was assessed by comparing the total $\mathrm{NH}_{4}{ }^{+}$released from all the clam beds in Cherrystone Inlet to the external watershed load, estimated at $29838 \mathrm{~kg} \mathrm{~N} \mathrm{yr}^{-1}$ (Kuschner 2015). According to the Virginia Marine Resources Commission, while the entire embayment is leased for shellfish aquaculture, only some of the leases are active. Based on actual coverage of clam aquaculture in Cherrystone Inlet of 181008 to $476048 \mathrm{~m}^{2}$ (estimated using aerial photographs taken in 2012 and GIS delineation; Emery 2015), we found that the total $\mathrm{NH}_{4}{ }^{+}$released from clam operations (without macroalgal uptake) is 38 to $99.8 \%$ that of the $\mathrm{N}$ load from the watershed. Therefore, this considerable amount of $\mathrm{N}$ recycled in the benthos fuels autotrophic production. Not only do cultivated clam beds provide nutrients, the shallow nets serve as a convenient structure for macroalgal attachment in close proximity to the nutrient source, allowing them to outcompete other primary producers (i.e. phytoplankton, benthic microalgae, and submerged aquatic vegetation) for nutrients, light, and space.

The 'bottom-up' influence of clam aquaculture on macroalgal production is certainly site-specific and dependent on a number of environmental factors such as external nutrient loading, residence time, and depth. For example, nutrient regeneration facilitated by bivalve aquaculture is likely more consequential in pristine systems with low external nutrient loading such as Cherrystone Inlet than in systems where allochthonous sources dominate. Additionally, the source of phytoplankton filtered by cultivated bivalves determines whether the nutrients regenerated in the benthos represent those already existing in the system or originating outside the system. If the residence time of the system is short, the particulate nutrients (i.e. phytoplankton) subsidizing bivalve growth are likely sourced from outside the system (e.g. the Chesapeake Bay) and delivered by incoming tides. If bivalves feed primarily on externally produced phytoplankton, the bivalves facilitate the regeneration of nutrients that would not be present if cultivation were not there.

\section{Macroalgae have a high capacity to sequester $\mathbf{N}$}

Unlike natural systems, macroalgal biomass on cultivated clam nets is controlled by aquaculture management practices, specifically the frequency of net sweeping. Nets are regularly cleaned to prevent detrimental effects on the clams due to decreased water flow as macroalgae accumulate. If the aquaculturists sweep the nets often enough to prevent densitydependent limitations of macroalgal production and $\mathrm{N}$ uptake (i.e. self-shading, competition for nutrients, etc.), it can be assumed that the macroalgae grow at optimal rates given the water temperature. Based on our estimates of seasonal macroalgal $\mathrm{N}$ demand, the number of clam beds (approx. 700, each $72 \mathrm{~m}^{2}$ ) within the studied farm, and assuming negligible $\mathrm{N}$ uptake in the winter months, macroalgae have the capacity to assimilate approx. $3652 \mathrm{~kg} \mathrm{~N} \mathrm{yr}^{-1}$ on this single farm, an amount equivalent to $116 \%$ of the annual $\mathrm{NH}_{4}{ }^{+}$released from the clam operation if no macroalgae were on the nets (3158 $\mathrm{kg} \mathrm{N} \mathrm{yr}^{-1}$ ) and assuming negligible release in the winter months from the clam sediments. Notably, macroalgal production rates and hence $\mathrm{N}$ uptake rates are likely overestimated as macroalgal $\mathrm{C}$ exudation, which could range from 0.5 to $40 \%$ of the total $C$ fixed (e.g. Khailov \& Burlakova 1969, Tyler \& McGlathery 2006), was not included in the calculation. Additionally, losses due to grazing and detachment/floating away were not taken into account. Nonetheless, given this high ability of macroalgae to intercept and temporarily sequester nutrients from the clam beds, harvesting the macroalgae could remove a significant amount of $\mathrm{N}$ from the system, decreasing the local nutrient input of the clam operation.

Though IMTA has generally been used to refer to a cultivation approach in which a fed species (finfish) is grown in combination with an organic extractive species (bivalves) and an inorganic extractive species (macroalgae) (Troell et al. 2009), to the extent that cultured clams in Cherrystone Inlet are serving to concentrate nutrients from a broader area, many of the same principles should apply. To develop an effi- 
cient IMTA program in which clams and macroalgae are harvested concurrently, additional research is needed to determine how macroalgal growth rates differ across the farm and due to aquaculture management practices (i.e. net cleaning). The assumption that the macroalgae grow at optimal rates on the clam nets is most certainly an overly simplified reality, which neglects density-dependent effects on growth and $\mathrm{N}$ uptake. Macroalgal growth rates and $\mathrm{N}$ demands are variable and strongly dictated by the frequency in which the nets are swept. After the nets are cleaned, growth rates will initially be low when little macroalgal biomass is present, and then increase as biomass accumulates. However, as the macroalgal mats become thick, self-shading will result in decreased growth rates and $\mathrm{N}$ demands. More accurate measurements of macroalgal function and nutrient uptake are required to develop best management practices within an IMTA framework; specifically the frequency of sweeping that optimizes macroalgal nutrient sequestration while minimizing negative effects of dense macroalgal mats on clam growth.

Macroalgal harvest would benefit the ecosystem by decreasing the risk of eutrophic conditions, particularly when macroalgae senesce and are mineralized. However, a successful IMTA in Cherrystone Inlet would require economic sustainability. In the United States, macroalgae have a limited market, making economic viability a challenge. Developing a market for the macroalgae, which is a naturally mixed species community, would likely be the largest challenge. However, possibilities exist; for example using the material as fertilizer on agriculture fields, as a carbon source for producing biofuel (Wei et al. 2013), or as feed for poultry farms (Abudabos et al. 2013). Clearly, many challenges would need to be addressed prior to implementing IMTA; however, the potential ecological benefit of harvesting the macroalgae should serve as motivation.

\section{Conclusions}

Our data suggest bivalve aquaculture may promote local primary production by recycling nutrients to the water column. The extensive clam cultivation operations in Cherrystone Inlet serve a significant role in nutrient cycling, altering the dominant primary producers. The clams filter particulate nutrients (i.e. phytoplankton) from the water column; a portion of this material is transformed to dissolved nutrients and subsequently to particulate nutrients again, but now in the form of macroalgae (Fig. 4). Although macroalgae temporarily sequester nutrients from the clam sediments, common management practice is to clean the macroalgae off the predator-exclusion nets and allowing them to drift away. The fate of these macroalgae is likely microbial decomposition, which releases the sequestered nutrients back to the water column and may lead to hypoxic conditions in the system. If macroalgae were harvested, a considerable amount of aquaculture-facilitated recycled $\mathrm{N}$ would be removed from the system. The potential ecological benefit in establishing an IMTA system in which both clams and macroalgae are harvested should be further assessed.

Acknowledgements. Many thanks to the aquaculturists who allowed us access to their operation; Jennifer Stanhope, Hunter Walker, and Gar Secrist for logistics, field and laboratory support; PG Ross, Edward Smith, Alan Birch, Sean Fate, Paige Smith, Jami Ivory and numerous interns for field help; Kyle Emery for providing clam aquaculture coverage estimates and maps. Discussions with Ashley Smyth, Daniele Nizzoli, and Marco Bartoli greatly improved the manuscript. We also thank the 3 anonymous reviewers for their constructive comments. This work was supported by Virginia Sea Grant (NA10OAR4170085, \# R/71515W), The National Science Foundation GK12 Fellowship (NSF DGE-0840804), and NSF Virginia Coast Reserve Long Term Ecological Research (LTER 0080381, 0621014). This paper is contribution No. 3459 of the Virginia Institute of Marine Science, College of William \& Mary.

\section{LITERATURE CITED}

Abudabos AM, Okab AB, Aljumaah RS, Samara EM, Abdoun KA, Al-Haidary AA (2013) Nutritional value of green seaweed (Ulva lactuca) for broiler chickens. Ital J Anim Sci 12:e28

Aller RC (1982) The effects of macrobenthos on chemical properties of marine sediment and overlying water. In: McCall PL, Tevesz MJS (eds) Animal-sediment relations. Springer, Boston, MA, p 53-102

> Anderson IC, McGlathery KJ, Tyler AC (2003) Microbial mediation of reactive nitrogen transformations in a temperate lagoon. Mar Ecol Prog Ser 264:73-84

- Anderson IC, Brush MJ, Piehler MF, Currin CA and others (2014) Impacts of climate-related drivers on the benthic nutrient filter in a shallow photic estuary. Estuar Coast $37: 46-62$

Asmus RM, Asmus H (1991) Mussel beds: limiting or promoting phytoplankton? J Exp Mar Biol Ecol 148:215-232

Bartoli M, Nizzoli D, Viaroli P, Turolla E, Castaldelli G, Fano EA, Rossi R (2001) Impact of Tapes philippinarum farming on nutrient dynamics and benthic respiration in the Sacca di Goro. Hydrobiologia 455:203-212

Bartoli M, Naldi M, Nizzoli D, Roubaix V, Viaroli P (2003) Influence of clam farming on macroalgal growth: a microcosm experiment. Chem Ecol 19:147-160

Bricker SB, Longstaff B, Dennison W, Jones A, Boicourt K, Wicks C, Woerner J (2008) Effects of nutrient enrichment 
in the nation's estuaries: a decade of change. Harmful Algae 8:21-32

Bricker SB, Rice KC, Bricker OP (2014) From headwaters to coast: influence of human activities on water quality of the Potomac River Estuary. Aquat Geochem 20:291-323

Burkholder JM, Shumway SE (2011) Bivalve shellfish aquaculture and eutrophication. In: Shumway SE (ed) Shellfish aquaculture and the environment. Wiley-Blackwell, Oxford, p 155-215

> Carlsson MS, Glud RN, Petersen JK (2010) Degradation of mussel (Mytilus edulis) fecal pellets released from hanging long-lines upon sinking and after settling at the sediment. Can J Fish Aquat Sci 67:1376-1387

Carlsson MS, Engström P, Lindahl O, Ljungqvist L, Petersen JK, Svanberg L, Holmer M (2012) Effects of mussel farms on the benthic nitrogen cycle on the Swedish west coast. Aquacult Environ Interact 2:177-191

> Chapelle A, Ménesguen A, Deslous-Paoli JM, Souchu P, Mazouni N, Vaquer A, Millet B (2000) Modelling nitrogen, primary production and oxygen in a Mediterranean lagoon. Impact of oysters farming and inputs from the watershed. Ecol Model 127:161-181

Christensen PB, Glud RN, Dalsgaard T, Gillespie P (2003) Impacts of longline mussel farming on oxygen and nitrogen dynamics and biological communities of coastal sediments. Aquaculture 218:567-588

Cline JD (1969) Spectrophotometric determination of hydrogen sulfide in natural waters. Limnol Oceanogr 14: 454-458

Cloern JE (1982) Does the benthos control phytoplankton biomass in south San Francisco Bay? Mar Ecol Prog Ser 9:191-202

> Cognie B, Barillé L, Rincé Y (2001) Selective feeding of the oyster Crassostrea gigas fed on a natural microphytobenthos assemblage. Estuaries 24:126-134

Cohen RR, Dresler PV, Phillips EJ, Cory RL (1984) The effect of the Asiatic clam, Corbicula fluminea, on phytoplankton of the Potomac River, Maryland. Limnol Oceanogr 29:170-180

Condon ED (2005) Physiological ecology of the cultured hard clam, Mercenaria mercenaria: a case study in Cherrystone Inlet, Virginia. MSc thesis, Virginia Institute of Marine Science, Gloucester Point, VA

De Casabianca ML, Laugier T, Collart D (1997) Impact of shellfish farming eutrophication on benthic macrophyte communities in the Thau lagoon, France. Aquacult Int 5: 301-314

> Doering PH, Oviatt CA, Kelly JR (1986) The effects of the filter-feeding clam Mercenaria mercenaria on carbon cycling in experimental marine mesocosms. J Mar Res 44:839-861

Emery K (2015) Coastal bivalve aquaculture carbon cycling, spatial distribution and resource use in Virginia, USA and Baja California, Mexico. MSc thesis, University of Virginia, Charlottesville, VA

Gibbs M, Funnell G, Pickmere S, Norkko A, Hewitt J (2005) Benthic nutrient fluxes along an estuarine gradient: influence of the pinnid bivalve Atrina zelandica in summer. Mar Ecol Prog Ser 288:151-164

- Gilbert F, Souchu P, Bianchi M, Bonin P (1997) Influence of shellfish farming activities on nitrification, nitrate reduction to ammonium and denitrification at the watersediment interface of the Thau lagoon, France. Mar Ecol Prog Ser 151:143-153

Giles H, Pilditch CA (2006) Effects of mussel (Perna canaliculus) biodeposit decomposition on benthic respiration and nutrient fluxes. Mar Biol 150:261-271

Gren IM, Lindahl O, Lindqvist M (2009) Values of mussel farming for combating eutrophication: an application to the Baltic Sea. Ecol Eng 35:935-945

Grenz C, Hermin MN, Baudinet D, Daumas R (1990) In situ biochemical and bacterial variation of sediments enriched with mussel biodeposits. Hydrobiologia 207: $153-160$

Hammen CS (1980) Marine invertebrates: comparative physiology. University Press of New England, Hanover, NH

> Hardison AK, Canuel EA, Anderson IC, Veuger B (2010) Fate of macroalgae in benthic systems: carbon and nitrogen cycling within the microbial community. Mar Ecol Prog Ser 414:41-55

$>$ Hardison AK, Anderson IC, Canuel EA, Tobias CR, Veuger B (2011) Carbon and nitrogen dynamics in shallow photic systems: interactions between macroalgae, microalgae, and bacteria. Limnol Oceanogr 56:1489-1503

Hatcher A, Grant J, Schofield B (1994) Effects of suspended mussel culture (Mytilus spp.) on sedimentation, benthic respiration and sediment nutrient dynamics in a coastal bay. Mar Ecol Prog Ser 115:219-235

Heijs SK, Azzoni R, Giordani G, Jonkers HM, Nizzoli D, Viaroli P, van Gemerden H (2000) Sulfide-induced release of phosphate from sediments of coastal lagoons and the possible relation to the disappearance of Ruppia sp. Aquat Microb Ecol 23:85-95

Hiwatari T, Kohata K, Iijima A (2002) Nitrogen budget of the bivalve Mactra veneriformis, and its significance in benthic-pelagic systems in the Sanbanse area of Tokyo Bay. Estuar Coast Shelf Sci 55:299-308

Joye SB, Hollibaugh JT (1995) Influence of sulfide inhibition of nitrification on nitrogen regeneration in sediments. Science 270:623-625

Kaspar HF, Gillespie PA, Boyer IC, MacKenzie AL (1985) Effects of mussel aquaculture on the nitrogen cycle and benthic communities in Kenepuru Sound, Marlborough Sounds, New Zealand. Mar Biol 85:127-136

Khailov KM, Burlakova ZP (1969) Release of dissolved organic matter from seaweeds and distribution of their total organic production to inshore communities. Limnol Oceanogr 14:521-527

Knepel K, Bogren K (2001) Determination of orthophosphate by flow injection analysis. QuikChem Method 31-11501-1-H, Lachat Instruments, Milwaukee, WI

Koroleff F (1983) Total and organic nitrogen. In: Grasshoff K, Ehrhardt M, Kremling K (eds) Methods of seawater analysis. Verlag-Chemie, Weinheim, p 162-169

- Kristensen E (2000) Organic matter diagenesis at the oxic/ anoxic interface in coastal marine sediments, with emphasis on the role of burrowing animals. Hydrobiologia 426:1-24

- Kristensen E, Blackburn TH (1987) The fate of organic carbon and nitrogen in experimental marine sediment systems: influence of bioturbation and anoxia. J Mar Res 45: 231-257

Kuschner MA (2015) A model of carrying capacity and ecosystem impacts in a large-scale, bivalve-dominated agroecosystem: hard clam aquaculture in Cherrystone Inlet, VA. MSc thesis, Virginia Institute of Marine Science, Gloucester Point, VA

Liao N (2001) Determination of ammonia in brackish or seawater by flow injection analysis. QuikChem Method 31- 
107-06-1-B, Lachat Instruments, Milwaukee, WI

Lindahl O, Hart R, Hernroth B, Kollberg S and others (2005) Improving marine water quality by mussel farming: a profitable solution for Swedish society. Ambio 34: 131-138

Magni P, Montani S, Takada C, Tsutsumi H (2000) Temporal scaling and relevance of bivalve nutrient excretion on a tidal flat of the Seto Inland Sea, Japan. Mar Ecol Prog Ser 198:139-155

> McGlathery KJ, Krause-Jensen D, Rysgaard S, Christensen PB (1997) Patterns of ammonium uptake within dense mats of the filamentous macroalga Chaetomorpha linum. Aquat Bot 59:99-115

Murphy RC, Kremer JN (1985) Bivalve contribution to benthic metabolism in a California lagoon. Estuaries 8: 330-341

National Research Council (NRC) (2000) Clean coastal waters: understanding and reducing the effects of nutrient pollution. National Academy Press, Washington, DC

$>$ Neubauer SC, Anderson IC (2003) Transport of dissolved inorganic carbon from a tidal freshwater marsh to the York River estuary. Limnol Oceanogr 48:299-307

> Nixon SW (1995) Coastal marine eutrophication: a definition, social causes, and future concerns. Ophelia 41: 199-219

Nixon S, Buckley B, Granger S (2001) Responses of very shallow marine ecosystems to nutrient enrichment. Hum Ecol Risk Assess 7:1457-1481

Nizzoli D, Welsh DT, Fano EA, Viaroli P (2006) Impact of clam and mussel farming on benthic metabolism and nitrogen cycling, with emphasis on nitrate reduction pathways. Mar Ecol Prog Ser 315:151-165

Nizzoli D, Bartoli M, Viaroli P (2007) Oxygen and ammonium dynamics during a farming cycle of the bivalve Tapes philippinarum. Hydrobiologia 587:25-36

Officer CB, Smayda TJ, Mann R (1982) Benthic filter feeding: a natural eutrophication control. Mar Ecol Prog Ser 9:203-210

Petersen JK, Hasler B, Timmermann K, Nielsen P (2014) Mussels as a tool for mitigation of nutrients in the marine environment. Mar Pollut Bull 82:137-143

Reay WG, Gallagher DL, Simmons GM (1992) Groundwater discharge and its impact on surface water quality in a Chesapeake Bay inlet. Water Resour Bull 28:1121-1134

Rose JM, Ferreira JG, Stephenson K, Bricker SB, Tedesco M, Wikfors GH (2012) Comment on Stadmark \& Conley (2011) Mar Pollut Bull 64:449-451

Rose JM, Bricker SB, Tedesco MA, Wikfors GH (2014) A role for shellfish aquaculture in coastal nitrogen management. Environ Sci Technol 48:2519-2525

Sauriau PG, Kang CK (2000) Stable isotope evidence of benthic microalgae-based growth and secondary production in the suspension feeder Cerastoderma edule (Mollusca, Bivalvia) in the Marennes-Oleron Bay. Hydrobiologia 440:317-329
Secrist RG (2013) Food availability and utilization for cultured hard clams. MSc thesis, Virginia Institute of Marine Science, Gloucester Point, VA

Sma RF, Baggaley A (1976) Rate of excretion of ammonia by the hard clam Mercenaria mercenaria and the American oyster Crassostrea virginica. Mar Biol 36:251-258

Smaal A, Stralen MV, Schuiling E (2001) The interaction between shellfish culture and ecosystem processes. Can J Fish Aquat Sci 58:991-1002

Smith P, Bogren K (2001) Determination of nitrate and/or nitrite in brackish or seawater by flow injection analysis colorimetry. QuikChem Method 31-107-04-1-E, Lachat Instruments, Milwaukee, WI

Smyth AR, Geraldi NR, Piehler MF (2013) Oyster-mediated benthic-pelagic coupling modifies nitrogen pools and processes. Mar Ecol Prog Ser 493:23-30

Spencer BE, Kaiser MJ, Edwards DB (1997) Ecological effects of intertidal Manila clam cultivation: observations at the end of the cultivation phase. J Appl Ecol 34: $444-452$

Stadmark J, Conley DJ (2011) Mussel farming as a nutrient reduction measure in the Baltic Sea: consideration of nutrient biogeochemical cycles. Mar Pollut Bull 62: 1385-1388

Stanhope JW, Anderson IC, Reay WG (2009) Base flow nutrient discharges from lower Delmarva Peninsula watersheds of Virginia, USA. J Environ Qual 38:2070-2083

> Strayer DL, Caraco NF, Cole JJ, Findlay S, Pace ML (1999) Transformation of freshwater ecosystems by bivalves. Bioscience 49:19-27

Sundbäck K, Miles A, Hulth S, Pihl L, Engström P, Selander E, Svenson A (2003) Importance of benthic nutrient regeneration during initiation of macroalgal blooms in shallow bays. Mar Ecol Prog Ser 246:115-126

Troell M, Joyce A, Chopin T, Neori A, Buschmann AH, Fang JA (2009) Ecological engineering in aquaculturepotential for integrated multi-trophic aquaculture (IMTA) in marine offshore systems. Aquaculture 297:1-9

Tyler AC, McGlathery KJ (2006) Uptake and release of nitrogen by the macroalgae Gracilaria vermiculophylla (Rhodophyta). J Phycol 42:515-525

Tyler AC, McGlathery KJ, Anderson IC (2001) Macroalgae mediation of dissolved organic nitrogen fluxes in a temperate coastal lagoon. Estuar Coast Shelf Sci 53:155-168

Tyler AC, McGlathery KJ, Anderson IC (2003) Benthic algae control sediment-water column fluxes of organic and inorganic nitrogen compounds in a temperate lagoon. Limnol Oceanogr 48:2125-2137

Valiela I, McClelland J, Hauxwell J, Behr PJ, Hersh D, Foreman K (1997) Macroalgal blooms in shallow estuaries: controls and ecophysiological and ecosystem consequences. Limnol Oceanogr 42:1105-1118

> Wei N, Quarterman J, Jin YS (2013) Marine macroalgae: an untapped resource for producing fuels and chemicals. Trends Biotechnol 31:70-77 

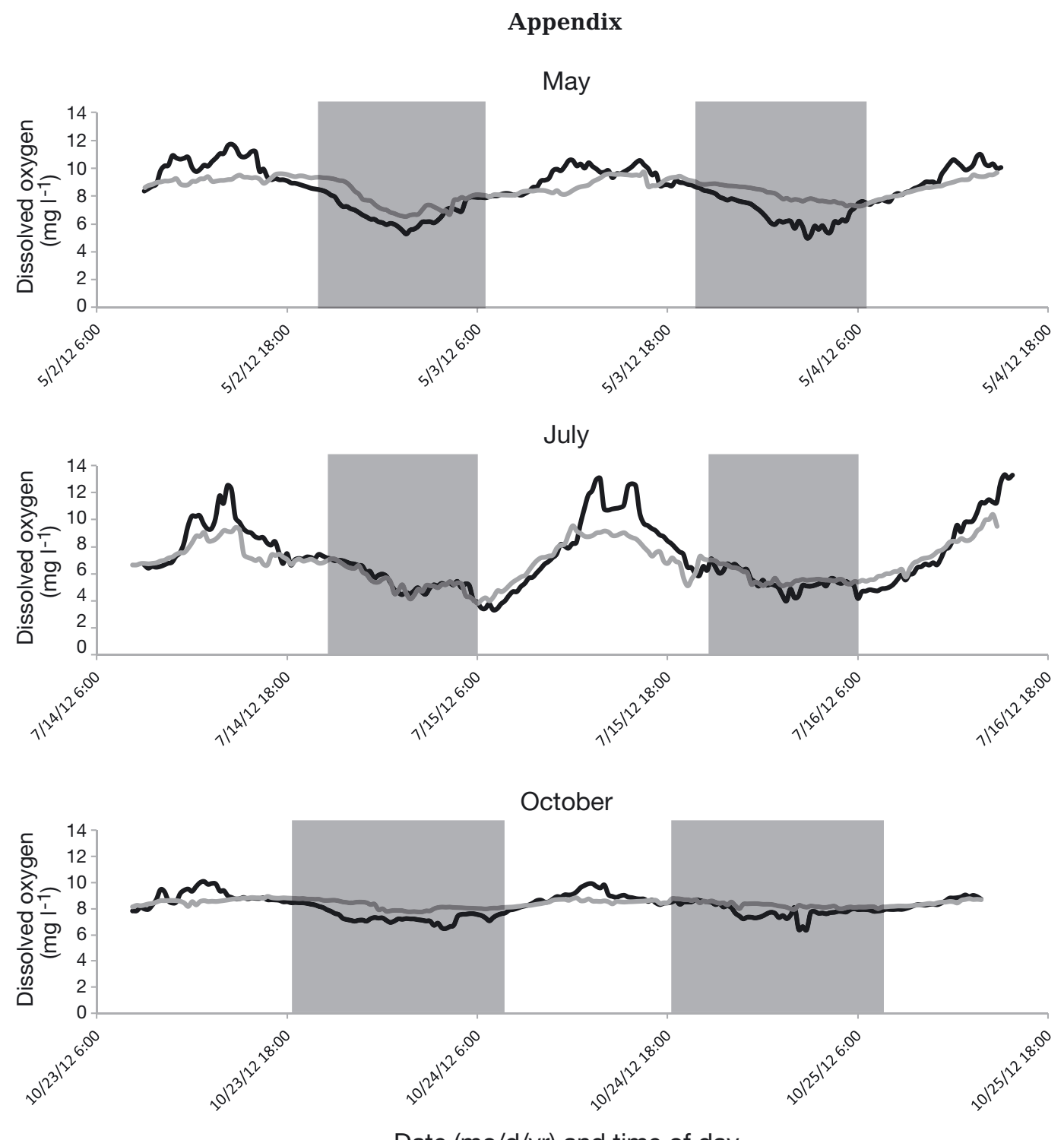

Date $(\mathrm{mo} / \mathrm{d} / \mathrm{yr})$ and time of day

Fig. A1. Continuous dissolved oxygen in the bottom water at the clam bed (black) and bare, uncultivated (gray) sites during each $3 \mathrm{~d}$ experiment. Shaded boxes represent nighttime hours. Dissolved oxygen probes were placed approx. $5 \mathrm{~cm}$ from the sediment-water interface and continuously monitored over the $3 \mathrm{~d}$ period

Editorial responsibility: Just Cebrian, Dauphin Island, Alabama, USA
Submitted: September 9, 2014; Accepted: April 2, 2015

Proofs received from author(s): June 2, 2015 